TOMASZ DYWAN

Instytut Historyczny Uniwersytetu Wrocławskiego

\title{
PRZEMYSŁ GAZOWNICZY WE LWOWIE W LATACH 1856-1914: PRZYCZYNEK DO DZIEJÓW INDUSTRIALIZACJI MIASTA
}

Zarys treści: Tekst omawia proces instalowania w przestrzeni miejskiej Lwowa oświetlenia gazowego oraz budowę i późniejsze modernizacje gazowni. Historię przemysłu gazowniczego we Lwowie charakteryzują podobne zjawiska społeczne i gospodarcze jak w przypadku innych miast austro-wegierskich i niemieckich (konflikty inwestora $\mathrm{z}$ miejskim samorządem i odbiorcami gazu, komunalizacja gazowni). Lwowskie gazownictwo na tle innych miast wyróżnia użycie nietypowych surowców do produkcji gazu (drewna, a później olejów naftowych) oraz stosunkowo późno występujący wzrost produkcji (po 1898 r.), będący skutkiem większej dostępności gazu zarówno dla miasta, jak i prywatnych odbiorców.

The content outline: The text discusses the installation of gas lighting in the urban space of Lviv, together with the construction and later modernisations of the city's gasworks. The history of gas industry in Lviv is characterised by social and economic phenomena similar to those of other Austro-Hungarian and German cities (conflicts between the investor, municipal government, and gas consumers, communalisation of the gasworks). What distinguishes the gas supply system of Lviv from those of other cities was the use of non-standard resources to gas production (wood, and then petroleum oils), and a relatively late rise in production (after 1898), resulting from the increased availability of gas to both the city, and private users.

Słowa kluczowe: Lwów, industrializacja, gazownictwo, miejskie zakłady przemysłowe, oświetlenie publiczne, Adam Teodorowicz, Niemieckie Kontynentalne Towarzystwo Gazowe w Dessau, Miejski Zakład Gazowy we Lwowie

Keywords: Lviv, industrialisation, gas system, municipal industrial plants, public lighting, Adam Teodorowicz, German Continental Gas Company of Dessau, Municipal Gasworks in Lviv 
W XIX w. w szybko rozwijajacych się miastach europejskich dokonywano poważnych inwestycji. Przedsiębiorcy prywatni i samorządy miejskie inwestowali w infrastrukturę, dzięki czemu, w wyniku upowszechnienia nowych technologii i innowacji, podnosił się standard życia mieszkańców. Proces ten wzmacniało dążenie ówczesnych elit do wcielania w życie koncepcji „miasta nowoczesnego”, którego mieszkańcy moga korzystać z udogodnień cywilizacyjnych, w tym oświetlenia przestrzeni publicznej. Prezentowany tekst ma na celu opisanie jednego $\mathrm{z}$ aspektów procesów modernizacji i industrializacji galicyjskiej stolicy².

\section{Technologia udostępniona społeczeństwu - narodziny przemysłu gazowniczego}

Oświetlenie przestrzeni, w jakiej żyją i pracują ludzie od zamierzchłych czasów stanowiło istotne wyzwanie dla człowieka. Starano się $\mathrm{mu}$ sprostać poprzez spalanie rozmaitych substancji - dzięki temu wydzielało się ciepło oraz sztuczne światło. Do ich uzyskiwania wykorzystywano m.in. łój, smołę, oliwę i wosk. Przed 1800 r. prowadzono poszukiwania bardziej efektywnych paliw, które mogłyby emitować

${ }^{1} \mathrm{~W}$ tym wypadku przymiotnik „nowoczesny” należy rozumieć jako oznaczający zróżnicowane właściwości, które odróżniają dziewiętnastowieczne miasta od „tradycyjnych” miast epoki feudalnej. Najczęściej historycy stosuja w badaniach takiej problematyki dychotomię następujących czynników, opisujących właściwości określeń tradycyjny/nowoczesny: stabilność/niestabilność struktur społecznych, gospodarka wiejsko-agrarna/miejsko-przemysłowa, patrymonializm/biurokracja itd.; zob. R.M. Lepsius, Soziologische Theoreme über die Sozialstruktur der „Moderne” und die „Modernisierung”, w: Studien zu Beginn der modernen Welt, red. R. Koselleck, Stuttgart 1977, s. 10-29; J.A. Tarr, D. Gabriel, Preface, w: Technology and the Rise of Networked City in Europe and America, red. J.A. Tarr, D. Gabriel, Philadelphia 1988, s. XIII-XVIII. O casusie Lwowa por. K. Pawłowski, Narodziny miasta nowoczesnego, w: Sztuka drugiej połowy XIX wieku. Materiały Sesji Stowarzyszenia Historyków Sztuki, Łódź listopad 1971, Warszawa 1973, s. 51-78.

${ }^{2}$ Inspiracje metodologiczne do badań industrializacji odnalazł autor w: T. Kemp, Industrializacja w XIX-wiecznej Europie, tłum. L. Garczyński, Wrocław 1998; R.H. Tilly, Industrialization as an Historical Process, w: European History Online, published by the Institute of European History, Mainz 2010, www.ieg-ego.eu/tillyr-2010-en (10 XII 2014). W odniesieniu do monarchii habsburskiej por. H. Matis, Austria. Industrialisation in a Multinational Settings, w: The Industrial Revolution in National Context: Europe and the USA, red. M. Teich, R. Porter, Cambridge 1996, s. 226-246; Z. Jindra, Základní pojmy a diskutované problemy, w: Dějiny hospodářství českých zemí. Od počátku industrializace do konce habsburské monarchie, red. I. Jakubec, Z. Jindra, Praha 2007, s. 9-29. 
więcej ciepła i światła $\mathrm{w}$ procesie spalania. Zwracano m.in. uwagę na występowanie w przyrodzie łatwopalnych wyziewów. Jednak do końca XVIII w. nikt nie pokusił się o wyjaśnienie, w jaki sposób człowiek mógłby wyprodukować i wykorzystać na masową skalę tego typu - jak wówczas pisano - „duchy”.

Właśnie w końcu XVIII w. produkcję gazu uzyskiwanego w wyniku procesu suchej destylacji drewna w specjalnie skonstruowanym piecu spopularyzował francuski inżynier cywilny Philippe Lebon (1767-1804). On też skonstruował lampę, która emitowała światło w procesie spalania uzyskanego gazu. Pomysł Lebona został wykorzystany w Anglii przez inżynierów zatrudnionych w firmie Boulton \& Watt. James Watt Jr. (1767-1848) umożliwił Williamowi Murdochowi (1754-1839) wykonanie w $1802 \mathrm{r}$. iluminacji fasady swojej fabryki maszyn parowych Soho Foundry, zasilanej gazem uzyskanym w wyniku prażenia węgla w wysokiej temperaturze bez dostępu powietrza. Ten eksperyment zwrócił uwagę przemysłowców z okolic Manchesteru, którzy byli zainteresowani poszukiwaniem tańszych możliwości oświetlania pomieszczeń fabrycznych. Pierwszą tego typu instalację wykonano dla przędzalni bawełny Georga Augustusa Lee w Salford. Okazało się, że produkcja gazu - uwzględniajacc nawet koszt wykonania instalacji - jest znacznie tańsza niż oświetlanie wnętrz fabryk świecami lub lampami olejowymi. Stąd oświetlenie gazowe umożliwiło wydłużenie czasu pracy robotników w miesiącach jesiennych i zimowych. Wkrótce właściciele innych fabryk zaczęli zlecać wykonanie instalacji do oświetlania gazem, ograniczając $\mathrm{w}$ ten sposób koszty oświetlania pomieszczeń fabrycznych (w latach 1805-1811 inżynierowie Boulton \& Watt wykonali instalację dla oświetlenia gazowego 31 fabryk) ${ }^{4}$.

Idea oświetlania gazem miast została podjęta przez Murdocha i Fredericka Alberta Winsora (właśc. Winzer, 1763-1830). Ich wieloletni trud popularyzacji gazu jako taniego i nowatorskiego produktu, za pomoca

${ }^{3}$ Ogólnie problematykę badań nad łatwopalnymi gazami do końca XVIII w. omawiają: J. Körting, Geschichte der deutschen Gasindustrie mit Vorgeschichte und bestimmenden Einflüssen des Auslandes, Essen 1963, s. 17-36; W. Schivelbusch, Disenchanted Night. The Industrialisation of Light in the Nineteenth Century, tłum. A. Davis, Berkeley-Los Angeles 1988, s. 15-17; L. Tomory, Progressive Enlightenment. The Origins of the Gaslight Industry 1780-1820, Cambridge (MA)-London 2012 (Transformations: Studies in the History of Science and Technology), s. 17-35.

${ }^{4}$ C. Hunt, A History of the Introduction of Gas Lighting, London 1907, s. 40-65; J. Körting, dz. cyt., s. 40-53; M.E. Falkus, The Early Development of the British Gas Industry 1790-1815, „The Economic History Review” 35, 1982, nr 2, s. 218-225; W. Schivelbusch, dz. cyt., s. 19-25; L. Tomory, dz. cyt., s. 47-50, 74-108; M.J. Szymański, Łódzka elektrownia i gazownia do 1939 roku, Łódź 2016, s. 17-18. 
którego można rozświetlić noc, doprowadził w końcu do pozyskania inwestorów i powołania w 1812 r. spółki Gas Light \& Coke Company. Miała ona zajmować się produkcja gazu, który mógł być wykorzystywany do oświetlenia przestrzeni publicznej, a nawet prywatnych zabudowań. W tym celu w latach 1812-1820 wybudowano w Londynie pierwszą na świecie gazownię wraz z siecią gazociagów ${ }^{5}$.

Industrializacja technologii pozyskiwania gazu dokonała się w wyniku ewolucyjnego procesu. Dzięki firmie Boulton \& Watt adaptowano znane już doświadczalne techniki pozyskiwania gazu do produkcji na większa skalę. Jednak dopiero działalność Winsora i założenie Gas Light \& Coke Company umożliwiło, poprzez umasowienie i udaną komercjalizację produkcji, ekspansję tej technologii ${ }^{6}$. Od końca drugiej dekady XIX w. nastapił szybki wzrost liczby zakładanych gazowni (od 1817 r. w Baltimore, od 1818 r. w Paryżu, od 1824 r. w Hanowerze, od 1826 r. w Berlinie, od 1835 r. w Wiedniu, od 1844 r. w Pradze) ${ }^{7}$. Do połowy XIX stulecia przemysł gazowniczy był domeną Anglików. To angielskie spółki przyczyniły się do ekspansji technologii produkcji gazu na kontynent, zapewniając sobie jednocześnie, zwłaszcza w miastach niemieckich, dominująca pozycję na rynku ${ }^{8}$. Zakłady, w których dziennie odgazowywano tony węgla, dostarczając paliwa niezbędnego do oświetlenia przestrzeni publicznej, a także infrastruktura gazociagów stały się jednym z głównych komponentów kultury materialnej dziewiętnastowiecznych miast.

${ }^{5}$ C. Hunt, dz. cyt., s. 95-116. Szczegółowo działalność Winsora i powołanie spółki opisuje L. Tomory, dz. cyt., s. 132-166, 186-217.

${ }^{6}$ Interpretacja tego procesu prowadzi do konstatacji, że nastapiła istotna „zmiana”, sprowadzająca się do zintensyfikowania i udoskonalenia produkcji oraz udostępnienia produktu na masowa skalę, co jest charakterystyczne dla szeregu zjawisk nazywanych w historiografii anglosaskiej „rewolucja przemysłowa”; zob.: C. More, Understanding the Industrial Revolution, New York-London 2010, s. 28-32; H. Jonas, Toward a Philosophy of Technology, w: Technology and Values. Essential Readings, red. C. Hanks, Chichester 2010, s. 13-18.

7 A. Elton, Gas for Light and Heat, w: A History of Technology, t. 4: The Industrial Revolution c. 1750 to c. 1850, red. C. Singer, E. Holmyard, A. Hall, T. Williams, Oxford 1958, s. 63-109; R. Riedl, Historie plynárenství a jeho vývoj v Československu, Praha 1978 (Sborník Vysoké školy chemicko-technologické v Praze, A. 20), s. 26-32.

${ }^{8} \mathrm{H}$. Wessel, Die Versorgung von Kommunen mit Wasser, Gas und elektrischer Energie von etwa 1850 bis 1914, w: Kommunalisierung im Spannungsfeld von Regulierung und Deregulierung im 19. und 20. Jahrhundert, red. J. Wysocki, Berlin 1995 (Schriften des Vereins für Socialpolitik. Gesellschaft für Wirtschafts- und Sozialwissenschaften. Neue Folge, 240), s. 65-67. 


\section{Czynniki warunkujące powstanie i rozwój przemysłu gazowniczego we Lwowie}

Lwów był wprawdzie od 1772 r. stolica „wymyślonej” przez cesarskich doradców prowincji - Królestwa Galicji i Lodomerii - lecz swoim wyglądem w połowie XIX stulecia przypominał bardziej miasto z epoki feudalnej niż stolicę największego kraju niewęgierskiej części monarchii. Jednak w dynamicznie zmieniających się uwarunkowaniach polityki wewnętrznej Cesarstwa Austriackiego po rewolucji 1848 r. sytuacja zaczęła się zmieniać. Namiestnictwo, kierowane od 1849 r. przez Agenora Gołuchowskiego (1812-1875), zainicjowało w lwowskim magistracie przedsięwzięcia, częściowo finansowane z budżetu Ministerstwa Handlu, Przemysłu i Robót Publicznych, mające na celu „upiększenie” i „uporządkowanie" miasta. Efektem tych inspiracji było założenie Ogrodu Botanicznego, uporządkowanie Ogrodu Jezuickiego i Cmentarza Łyczakowskiego, rozpoczęcie regulacji ulic i nowej zabudowy w obrębie dawnego miasta średniowiecznego oraz wprowadzenie zarządzeń mających na celu zachowanie „czystości i porządku”. W kontekście takich działań magistratu należy upatrywać ideę założenia we Lwowie zakładu gazowego oraz stworzenie infrastruktury umożliwiającej oświetlenie miasta. Można zatem założyć, że stołeczny charakter Lwowa wymagał od zarządzających krajem habsburskich urzędników wprowadzania oświetlenia gazowego, które - parafrazując słowa Józefa Białyni Chołodeckiego (1852-1934) - było postrzegane jako przejaw „wielkiego postępu”. Idąc tokiem myślenia ówczesnej kadry urzędniczej, można to uznać za jeden z symptomów „cywilizowania” stolicy prowincji, uchodzącej za najbardziej zacofaną w monarchii Habsburgów ${ }^{10}$.

Miasto nie było w stanie samodzielnie sfinansować budowy gazowni i infrastruktury do rozprowadzania gazu. W latach 50. XIX w. finanse Lwowa charakteryzował stały deficyt, który pokrywano wysoko oprocentowanymi pożyczkami. W tym czasie na terenie Galicji brakowało instytucji finansowych o dużym kapitale, które byłyby w stanie finansować tak jak miało to miejsce Anglii i krajach niemieckich - przedsięwzięcia

${ }^{9}$ M. Prokopovych, Habsburg Lemberg. Architecture, Public Space and Politics in the Galician Capital, West Lafayette 2009, s. 32-34, 77-78.

${ }^{10}$ J. Białynia Chołodecki, Lwów w XIX stuleciu, Lwów 1928, s. 12. O funkcjonowaniu samorządu miejskiego w tym czasie por.: K. Ostaszewski-Barański, Ustawa prowizoryczna (1848-1870), w: Miasto Lwów w okresie samorzadu 1871-1895, Lwów 1896, s. 4-25; S. Grodziski, Historia ustroju społeczno-politycznego Galicji 1772-1848, Wrocław 1971, s. 51-53; M. Prokopovych, dz. cyt., s. 37-43; L. Wolff, The Idea of Galicia. History and Fantasy in Habsburg Political Culture, Stanford 2010, s. 20. 
długoterminowe i przemysłowe. Działało zaledwie kilka banków (do 1873 r. było ich osiem), które były nastawione na udzielanie krótkoterminowych pożyczek na wysoki procent ${ }^{11}$. Dlatego lwowscy radni za najwyższy priorytet uznali utrzymanie zrównoważonego budżetu i niechętnie upoważniali urzędników magistratu do zaciagania pożyczek ${ }^{12}$. Stąd przy budowie gazowni miejski samorząd korzystał ze sprawdzonego w miastach Europy Zachodniej modelu partnerstwa publiczno-prywatnego, polegającego na finansowaniu inwestycji przez spółkę zrzeszająca prywatnych inwestorów. W zamian spółka otrzymywała monopol na produkcję i sprzedaż gazu w mieście ${ }^{13}$. Nota bene podobnie postapiono w 1879 r. w przypadku budowy linii tramwaju konnego, zapewniających masowy transport publiczny. Tę inwestycję w zrealizowała we Lwowie Triesteńska Spółka Tramwajowa (Società Triestina Tramway) ${ }^{14}$.

Warunki rozwoju przemysłu gazowniczego w stolicy Galicji okazały się pomyślne. Przede wszystkim ludność miasta zwiększała się systematycznie (z $70384 \mathrm{w} 1857$ do ponad 170 tys. w 1910 r.). Lwów rozbudowywał się, co w konsekwencji prowadziło do wytyczania nowych ulic, które wymagały oświetlenia ${ }^{15}$. Wzrost liczby mieszkańców, połączony z rozwojem budownictwa, wymusił na przełomie XIX i XX stulecia kolejną falę inwestycji infrastrukturalnych (centralny wodociag, centralna rzeźnia miejska, ogólnospławna kanalizacja, tramwaj elektryczny i elektrownia). W wyniku inicjatywy prezydenta Lwowa Edmunda Mochnackiego (1836-1902, urząd prezydenta pełnił w latach 1887-1896) i radnego

${ }^{11}$ H. Nowak, Bankowość w Polsce, t. 1, Warszawa 1932 (Prace Biura Ekonomicznego Banku Polskiego, 4), s. 14-15; W. Saryusz-Zaleski, Dzieje przemystu w b. Galicji 1804-1929 ze szczególnym uwzględnieniem historii rozwoju S.A. L. Zieleniewski $i$ Fitzner Gamper. Wydawnictwo z okazji 125 letniego jubileuszu, Kraków 1930, s. 21-24; M. Ben-Joseph, Adversities of Autonomy. Bank Krajowy Królestwa Galicyi $i$ Lodomeryi and the Politics of Credit in Galicia 1870-1913, Kraków 1999, s. 30-31. Strategię finansowania tego typu przedsięwzięć od lat 20. XIX w. opisuje C. More, dz. cyt., s. 30-33.

12 S. Hoszowski, Ekonomiczny rozwój Lwowa w latach 1772-1914, Lwów 1935, s. 99-105; Ł.T. Sroka, Rada Miejska we Lwowie w okresie autonomii galicyjskiej 1870-1914. Studium o elicie władzy, Kraków 2012 (Uniwersytet Pedagogiczny im. Komisji Edukacji Narodowej w Krakowie. Prace Monograficzne, nr 621), s. 126-131.

${ }^{13}$ R. Banik-Schweitzer, Liberale Kommunalpolitik in Bereichen der technischen Infrastruktur Wiens, w: Wien in der liberalen Ära, Wien 1978 (Forschungen und Beiträge zur Wiener Stadtgeschichte, 1), s. 91-119; M.J. Szymański, dz. cyt., s. 13-16.

${ }^{14}$ M.J. Szynhel'skyj, Peredumowy $i$ istorija stworennija kinnoho tramwaju u Lwowi, „Doslidzhennia z istorii techniki” 6, 2005, s. 95-102.

${ }_{15}$ M. Kowalczuk, Rozwój terytorialny miasta, w: Miasto Lwów w okresie samorzqdu..., s. 299-351; K. Wnęk, L. Zyblikiewicz, E. Callahan, Ludność nowoczesnego Lwowa w latach 1857-1938, Kraków 2006, s. 31-32. 
Emila Byka (1845-1906) rada miejska powzięła uchwałę o zaciagnięciu tzw. dziesięciomilionowej (w guldenach) pożyczki w formie obligacji komunalnych, zabezpieczonych hipoteka obciążająca dobra ziemskie należące do miasta ${ }^{16}$. Dzięki uzyskanym za pośrednictwem Banku Krajowego Królestwa Galicji i Lodomerii kapitałom podjęto ambitny program modernizacji galicyjskiej stolicy. Obją on także istniejąca od 1858 r. gazownię i sieć gazowa.

\section{Prawne aspekty funkcjonowania przemysłu gazowniczego do 1898 r.}

Największe doświadczenie w finansowaniu i budowie gazowni w miastach niemieckich, w tym także w Wiedniu, miała angielska spółka Imperial Continental Gas Association ${ }^{17}$. Jednak nie była ona zainteresowana inwestowaniem kapitału na peryferiach Cesarstwa. Takich oporów nie miała dyrekcja Niemieckiego Kontynentalnego Towarzystwa Gazowego w Dessau (Deutschen Continental-Gas-Gesellschaft zu Dessau, DCGG), powołana na mocy uzyskanej w 1855 r. koncesji księcia Anhalt-Dessau. Spółka ta, dysponując kapitałem 500 tys. talarów, konkurowała $\mathrm{z}$ dominującymi w niemieckich miastach firmami angielskimi, poszukując możliwości inwestycyjnych nie tylko na rodzimym rynku, ale także w Rosji i monarchii Habsburgów. Efektem tej polityki było sfinansowanie w latach 1856-1857 budowy gazowni dla Krakowa i Warszawy ${ }^{18}$.

12 II 1856 r. gmina miasta Lwowa zawarła umowę z DCGG na produkcję i dostarczenie gazu dla oświetlenia miasta oraz użytku prywatnego mieszkańców. Jej zapisy były zbliżone do warunków kontraktów, jakie DCGG zawarło w tymże roku z władzami Krakowa i Warszawy ${ }^{19}$.

${ }^{16}$ K. Ostaszewski-Barański, Poglad na działalność reprezentacji król. stołecznego miasta Lwowa w okresie 1871-1895, w: Miasto Lwów w okresie samorzadu..., s. 120-122; Ł.T. Sroka, dz. cyt., s. 132-133, 332-333. O działalności Banku Krajowego Królestwa Galicji i Lodomerii z Wielkim Księstwem Krakowskim w kwestii kredytowania samorządów miejskich por. K. Broński, Rozwój gospodarczy większych miast galicyjskich w okresie autonomii, Kraków 2003, s. 52-55.

$17 \mathrm{O}$ założeniu i działalności spółki w miastach niemieckich zob. J. Körting, dz. cyt., s. $103-117$.

${ }_{18}$ F. Brückner, Die Vorgeschichte des VEB Waggonbau Dessau von 1895 bis 1945, „Jahrbuch für Wirtschaftsgeschichte” 3, 1962, nr 1, s. 137-138; J. Körting, dz. cyt., s. $118-121$.

${ }_{19}$ M. Seifert, Historia rozwoju krakowskiej gazowni miejskiej, „Przegląd Gazowniczy i Wodociagowy. Organ Zrzeszenia Gazowników i Wodociagowców Polskich” 4, 
Lwowski kontrakt został zatwierdzony przez Namiestnictwo 19 lutego tego roku i wszedł w życie 1 IX $1858 \mathrm{r}$. Na jego mocy dyrekcja DCGG zobowiązała się wybudować zakład gazowy z własnych środków, w zamian za co uzyskała do nieodpłatnego używania grunt pod budowę gazowni przy ul. Słonecznej (ostatecznie gazownię wybudowano przy ul. Źródlanej) oraz monopol na dostarczanie gazu dla miasta na okres 25 lat. Po upływie tego czasu, tj. 1 IX 1883 r., miasto miało prawo pierwokupu zakładu gazowego za kwotę szesnastokrotnej wartości jego średniego rocznego dochodu obliczanego $\mathrm{z}$ ostatnich 10 lat działalności. Jeśli miasto nie zdecydowałoby się na wykup na tych zasadach, wówczas czas obowiazywania kontraktu przedłużano na dalszych 15 lat, po czym zakład gazowy miał bezwarunkowo przejść na własność miasta. W szczegółowych zapisach kontraktu ustalono, iż DCGG zobowiązuje się oświetlić centrum miasta i główne ulice. Inne miano oświetlać dopiero wówczas, gdy na 100 stóp wiedeńskich (31,58 m) długości ulicy znajdzie się sześć ujęć gazu. Koszty materiałów do ułożenia sieci gazowej i latarń zdecydowano się pokryć po połowie przez gminę miasta Lwowa i DCGG. Zrywanie bruków i trotuarów pod położenie sieci oraz ponowne ich ułożenie w całości miało finansować DCGG. Każda latarnia gazowa miała spalać co najwyżej 5 stóp ${ }^{3}$ gazu/h $(0,14 \mathrm{~m})$, dzięki czemu siła światła powinna wynosić 12 świec. W przypadku stwierdzenia mniejszej jasności DCGG winno płacić szczegółowo ustalone kary. Cenę 1000 stóp ${ }^{3}$ $\left(28,32 \mathrm{~m}^{3}\right)$ gazu ustalono na 5 guldenów dla gminy miasta Lwowa i na 6 guldenów dla odbiorców prywatnych. Przewidziano także obniżkę ceny dostarczanego gazu w przypadku znacznego wzrostu jego konsumpcji ${ }^{20}$.

Problem skomunalizowania lwowskiego przemysłu gazowniczego należy rozpatrywać w szerszym kontekście funkcjonowania tej gałęzi przemysłu, zwłaszcza w miastach niemieckich i monarchii habsburskiej. Podobnie jak w Wielkiej Brytanii, od lat 20. XIX w. samorządy tamtejszych miast decydowały się na oddanie monopolu na produkcję i dostarczanie gazu spółkom zrzeszającym prywatnych inwestorów na

1924, nr 5, s. 129; J. Doliński, 100 lat gazowni krakowskiej, w: Sto lat gazowni krakowskiej, Kraków 1956, s. 12-13; E. Strasburger, Gospodarka naszych wielkich miast Warszawa, Łódż, Kraków, Lwów, Poznań na podstawie budżetu na rok 1911 w porównaniu z latami poprzednimi, Kraków-Warszawa 1913, s. 244-245, 261-262.

${ }^{20}$ Archiwum Państwowe Obwodu Lwowskiego (dalej: DALO), Magistrat król. stoł. miasta Lwowa (dalej: f. 3), op. 1, sp. 3168, Kontrakt [tłum. z niem.] zawarty pomiędzy reprezentacja kr. stoł. miasta Lwowa, działajaca na zasadzie uchwały z 9 II 1856 z jednej strony, a Panem D. Janem v. Unruh radca rządowym, pełnomocnikiem Niemieckiego Kontynentalnego Towarzystwa Gazowego w Dessau z drugiej strony, o oświetlenie miasta Lwowa gazem umówiony i zawarty z zastrzeżeniem zatwierdzenia przez c.k. Namiestnictwo, k. 48-55. 
okres 10-25 lat. Spółki gazowe obierały jednak kurs na utrzymanie swojego monopolu na rynku, dążąc do renegocjacji zapisów zawartych umów koncesyjnych. Argumentowano, że samorządy miejskie nie będa w stanie racjonalnie zarządzać zakładem przemysłowym czy też inwestować w rozwijajaca się technologię produkcji gazu, w tym także wykorzystywania produktów ubocznych (koksu, wody amoniakalnej, smoły pogazowej ${ }^{21}$. Takie argumenty przekonały niektóre miejskie samorządy. Jednak później okazywało się, że spółki gazowe, dążąc do maksymalizacji zysków, zainteresowane są w utrzymywaniu wysokich cen za dostarczany produkt. Było to powodem wielu konfliktów, do jakich dochodziło pomiędzy spółkami gazowymi a władzami miejskimi i konsumentami gazu. Dlatego po pierwszej fali komunalizacji niektórych zakładów gazowych w wielkich miastach niemieckich (w latach 60 . XIX w.) większość samorządów miejskich dążyła do ich przejęcia na własność. Duże miasta, które zrezygnowały z prawa własności do gazowni w zamian za mgliste perspektywy obniżania cen gazu oraz rozbudowy i modernizacji dotychczas używanych zakładów, zmuszone zostały do wzniesienia konkurencyjnych gazowni na własny koszt bądź przyciagnięcia kolejnego inwestora, który mógłby sfinansować ich budowę ${ }^{22}$. Warto w tym względzie przypomnieć, że rady miejskie Pragi w 1867 (gazownia w dzielnicy Žižkov), a Budapesztu w 1877 r. zdecydowały się sfinansować budowę własnych gazowni, konkurencyjnych wobec już funkcjonujacych pod zarządem spółek gazowych ${ }^{23}$.

Także dyrekcja DCGG wobec satysfakcjonującej dochodowości lwowskiej gazowni starała się skłonić samorząd miejski do rezygnacji z prawa wykupu zakładu. W sierpniu $1864 \mathrm{r}$. zaproponowano władzom miasta zawarcie nowego kontraktu ${ }^{24}$. W przedłożonym projekcje $\mathrm{w}$ zamian za

${ }^{21}$ H.-D. Brunckhorst, Kommunalisierung im 19. Jahrhundert dargestellt am Beispiel der Gaswirtschaft in Deutschland, München 1978, s. 40-45.

${ }_{22}$ W.R. Krabbe, Kommunalpolitik und Industrialisierung. Die Entfaltung der städtischen Leistungsverwaltung im 19. und frühen 20. Jahrhundert. Fallstudien zu Dortmund und Münster, Stuttgart 1985 (Schriften Deutschen Instituts für Urbanistik, 74), s. 42-49; G. Ambrosius, Die wirtschaftliche Entwicklung von Gas-, Wasser- und Elektrizitätswerken ( $a b$ ca. 1850 bis zur Gegenwart), „Zeitschrift für Unternehmensgeschichte" 42, 1987, s. 127-128; H. Wessel, dz. cyt., s. 66-74.

${ }^{23}$ R. Riedl, Historie plynárenství..., s. 70-71; H.-D. Brunckhorst, dz. cyt., s. 59-68; G. Melinz, S. Zimmermann, Die aktive Stadt. Kommunale Politik zur Gestaltung städtischer Lebensbedingungen in Budapest, Prag und Wien (1867-1914), w: Wien-Budapest - Prag. Blütezeit der Habsburgermetropolen. Urbanisierung, Kommunalpolitik, gesellschaftliche Konflikte (1867-1918), red. G. Melinz, S. Zimmermann, Wien 1996, s. $146-147$.

${ }^{24}$ DALO, f. 3, op. 1, sp. 2367, Wniosek w przedmiocie zmiany umowy z 12 II 1856 zawartej z Towarzystwem w Dessau o dostarczenie gazu dla miasta Lwowa, k. 3-19v. 
zrzeczenie się praw własności do gazowni oferowano obniżenie ceny dostarczanego gazu. Przewidywano ponadto dalsze rozszerzanie sieci gazowej o ponad $11 \mathrm{~km}$ na zasadach ustalonych w kontrakcie z $1856 \mathrm{r}$. oraz kolejne obniżenie ceny produkowanego gazu, stosownie do wzrostu jego konsumpcji ${ }^{25}$.

W myśl § 43 Statutu miasta Lwowa 30 III 1871 r. rada miejska powołała specjalną komisję „dla sprawy gazowej”. Wśród członków tego gremium ekspertem $\mathrm{w}$ zakresie produkcji i eksploatacji gazu był inż. Ludwik Wolski. Był on zwolennikiem proponowanego przez DCGG rozwiązania, które z uwagi na konieczność rozbudowy i modernizacji użytkowanej gazowni uważał za korzystne dla miasta ${ }^{26}$. Jednak wobec pojawiających się wattpliwości postanowiono wnikliwie zbadać całą sprawę. Magistrat poddał dokładnej analizie zużycie gazu we Lwowie, zapisy umów gazowych innych miast, jakie owe miasta zawierały ze spółkami gazowymi, a także prowadził ożywione konsultacje z magistratami innych miast austriackich i niemieckich ${ }^{27}$. Sprawa przeciagała się i z tego powodu, że po dosyć burzliwych dyskusjach radni nie byli w stanie przegłosować wiążącej uchwały. Wybrana w kolejnych wyborach nowa rada miejska 17 III 1874 r. delegowała członków kolejnej komisji gazowej. Również to gremium, po analizie kolejnej propozycji renegocjacji kontraktu przedłożonej przez dyrekcję DCGG, dokonanej przez inżynierów Feliksa Strzeleckiego i Teobalda Semilskiego, uznało, że proponowane warunki sa korzystne dla miasta. Stąd w przedłożonym radnym opracowaniu komisja opowiedziała się za przedłużeniem kontraktu z DCGG na 60 lat (tj. aż do 1958 r.), w zamian za obniżkę ceny dostarczanego gazu ${ }^{28}$.

Wniosek ten został jednak skierowany do ponownego rozpatrzenia przez radnych, co w praktyce oznaczało jego odrzucenie. Rada miejska zleciła wykonanie kolejnego opracowania pod katem sprawdzenia, które rozwiązanie będzie bardziej korzystne dla miasta, zgodnie z zapisami umowy z 1856 r. - wykupienie zakładu gazowego w 1883 r. czy

${ }^{25}$ DALO, f. 3, op. 1, sp. 2960, Sprawozdanie komisji rady miejskiej we Lwowie w sprawie gazowej, oprac. F. Strzelecki, T. Semilski, Lwów, 8 I 1877 r., k. 1r-v; DALO, f. 3, op. 1, sp. 3168, Umowa dodatkowa [projekt], k. 56-64v.

${ }^{26}$ DALO, f. 3, op. 1, sp. 3425, Sprawozdanie komisji gazowej, oprac. P. Skwarczyński, L. Wolski, Lwów, 27 VIII 1871 r., k. 6r-v. O powoływaniu i funkcjonowaniu komisji miejskich por. K. Ostaszewski-Barański, Poglad na dziatalność..., s. 74-75.

${ }^{27}$ DALO, f. 3, op. 1, sp. 3168, k. 10-35; DALO, f. 3, op. 1, sp. 2960, Sprawozdanie komisji rady miejskiej we Lwowie w sprawie gazowej, oprac. F. Strzelecki, T. Semilski, Lwów, 8 I 1877 r., k. 2r-v.

${ }^{28}$ DALO, f. 3, op. 1, sp. 2960, Sprawozdanie komisji rady miejskiej we Lwowie w sprawie gazowej, oprac. F. Strzelecki, T. Semilski, Lwów, 8 I 1877 r., k. 2v-12. 
cierpliwe wyczekiwanie do jego przejęcia w 1898 r. Kwestia ta wzbudziła zainteresowanie inżynierów galicyjskich zrzeszonych w Towarzystwie Politechnicznym i była przedmiotem szczegółowych polemik, podejmowanych na łamach wydawanego we Lwowie fachowego czasopisma z zakresu techniki - „Dźwigni”" ${ }^{2}$. Miejska Izba Obrachunkowa nie posiadała dostatecznych danych, aby móc obliczyć wysokość ceny wykupu zakładu gazowego. Dyrekcja DCGG zasłaniała się tajnościa tych danych. Było to najwyraźniej celowe działanie władz spółki, która starała się ukryć przed samorządem miejskim wielkość dochodów czerpanych z monopolu na produkcję i sprzedaż gazu we Lwowie.

Podobne kontrowersje w kwestii renegocjowania kontraktu z DCGG miała gmina miasta Krakowa, której radni również zastanawiali się nad przejęciem gazowni w 1882 r. Urzędnicy miejscy, podobnie jak to miało miejsce we Lwowie, nie mogli uzyskać wglądu do ksiag przychodów i rozchodów zakładu gazowego. W korespondencji z lwowskim magistratem informowali, że zlecane przez miasto pomiary intensywności światła wykazywały jasność o 10-20\% mniejszą od tej ustalonej kontraktem zawartym w 1856 r. Stąd gmina miasta Krakowa wydała dwa pozwy sądowe o niedotrzymanie kontraktu i nieudostępnienie ksiag rachunkowych przez DCGG ${ }^{30}$. Spór Krakowa z DCGG zaostrzył się do tego stopnia, że wypowiedziano spółce koncesję, grożąc wybudowaniem konkurencyjnej gazowni. Krakowianie w akcie poparcia tej polityki zaprzestali oświetlania pomieszczeń gazem, w efekcie czego dyrekcja DCGG zmuszona została do obniżenia kwoty wykupu gazowni przez Kraków z miliona do 460 tys. guldenów. Za taką sumę gmina miasta Krakowa wykupiła na własność zakład gazowy w kwietniu $1886 \mathrm{r}^{31}$

Okoliczności wykupu krakowskiej gazowi utwierdziły lwowskich radnych w przekonaniu, że nie można liczyć na lojalne współdziałanie DCGG z władzami miasta. Po dokonaniu oceny dostępnych miejskim urzędnikom danych o przychodach gazowni ${ }^{32}$ sprawozdawcy

${ }^{29}$ H. Baum, Kilka słów w kwestii zakupna zakładu gazowego przez gmine miasta Lwowa, „Dźwignia. Organ Towarzystwa Ukończonych Techników we Lwowie” 5, 1881, nr 3-5, s. 33-35, 40-41, 56-58; por. DALO, f. 3, op. 1, sp. 4431, R. Banaszkiewicz do magistratu miasta Lwowa, z Tarnowa, 31 III 1881 r., k. 38-39v.

${ }^{30}$ DALO, f. 3, op. 1, sp. 2961, Odezwa magistratu miasta Krakowa do magistratu kr. stoł. miasta Lwowa, Kraków, 4 IV 1877 r., k. 11-13.

${ }^{31}$ Sprawa gazowa $w$ Krakowie, „Kurier Lwowski” 3 II 1886, s. 2; M. Seifert, dz. cyt., s. 129-130; J. Doliński, dz. cyt., s. 14-15.

32 Urzędnicy Miejskiej Izby Obrachunkowej w drodze wyjątku znali przychody gazowni z lat 1873-1876. Rosły one od kwoty 61 363,80 do 76 612,37 guldenów; zob. DALO, f. 3, op. 1, sp. 2961, Sprawozdanie Miejskiej Izby Obrachunkowej, Lwów, 3 XI 1877 r., k. 19. 
komisji gazowej wykonali szacunkowe obliczenia i postulowali przejęcie gazowni na własność miasta dopiero w 1898 r., mimo że taka decyzja oznaczała utrzymanie wysokich cen za dostarczany gaz, a tym samym powolny wzrost jego konsumpcji w stosunku do innych „wielkich" miast monarchii ${ }^{33}$. Ostatecznie na posiedzeniu rady miejskiej 20 VII 1882 r. zdecydowano wybrać najbardziej zdaniem radnych korzystne rozwiązanie, polegajace na przedłużeniu kontraktu na dalszych 15 lat, w zamian za bezwarunkowe przejęcie gazowni na własność miasta 1 IX 1898 r.

Gmina miasta Lwowa przejmowała gazownię w atmosferze podekscytowania panującego wśród elit zarządzających miastem. Wyrazem tego był opublikowany na łamach „Gazety Narodowej” tekst profesora lwowskiej c.k. Szkoły Politechnicznej - Romana Gostkowskiego (1837-1912), który zwracał uwagę, że przejęty zakład „ma wyrabiać światło lepsze, i ma go wyrabiać więcej, musi go wyrabiać tanio, aby przy niskich cenach mieć [wystarczajace - T.D.] dochody". Profesor porównywał zaistniała sytuację do rozpoczęcia przez Wiedeń w $1898 \mathrm{r}$. budowy olbrzymiej gazowni w dzielnicy Simmering, celem stworzenia konkurencji dla wiedeńskich gazowni Imperial Continental Gas Association. Dzięki zrealizowaniu tej inwestycji spodziewano się znacznie obniżyć ceny za dostarczany mieszkańcom Wiednia gaz ${ }^{34}$. W lwowskiej prasie opisywano zaś posiedzenie rady miejskiej z 22 X 1897 r., podczas którego radni z pogardą wypowiadali się o stosunkach gminy z DCGG, określając je dosadnie „dessauską niewolą. Żadnych szans nie miała zatem propozycja administrowania lwowska gazownia przez kolejne 10 lat, przedłożona przez dyrekcję DCGG wiosną $1895 \mathrm{r}$. w zamian za obniżenie cen gazu i podział zysków z jego sprzedaży $\mathrm{z}_{\text {miastem }}{ }^{35}$.

${ }^{33}$ DALO, f. 3, op. 1, sp. 3168, Sprawozdanie sekcji II rady miejskiej w sprawie gazowej, oprac. M. Madejski, F. Zuker, Lwów, 26 VI 1882 r., k. 74v-76v, 78-105v. W tym czasie ceny $1 \mathrm{~m}^{3}$ gazu po przejęciu gazowni przez gminę miasta Krakowa były o połowę niższe niż we Lwowie; por. J. Doliński, dz. cyt., s. 16.

${ }^{34}$ R. Gostkowski, Nasza gazownia, „Gazeta Narodowa” 2 IX 1898, s. 1; DALO, Miejski Zakład Gazowy we Lwowie (dalej: f. 599), op. 1, sp. 2, Gazownia lwowska i jej objęcie przez gminę miasta Lwowa, oprac. R. Gostkowski, Lwów, 25 I 1896 r., k. 100-121. O budowie miejskiej gazowni w wiedeńskiej dzielnicy Simmering por. E. Karel, Das städtische Gaswerk, w: Wien am Anfang des XX. Jahrhunderts. Ein Führer in technischer und künstlerischer Richtung, t. 1, red. P. Kortz, Wien 1905, s. 241-242.

${ }^{35}$ Rada miasta Lwowa (z dnia 22 października), „Gazeta Lwowska” 23 X 1897, s. 4; Posiedzenie Rady miejskiej dnia 22 października, „Gazeta Narodowa” 23 X 1897, s. 2 . 


\section{Budowa gazowni oraz podjęte rozbudowy i modernizacje zakładu do 1914 r.}

Kompleks pierwszej lwowskiej gazowni z wiosny 1858 r. składał się z czterech prostopadłościennych budynków, spośród których największym był wystawiony na środku parceli przy ul. Źródlanej budynek piecowni ${ }^{36}$. Planowano wymurować w nim baterię kilku pieców z płaskimi rusztami i żeliwnymi retortami, służącymi do odgazowywania surowca. $21 \mathrm{~V} 1858$ r. użyto dwóch pieców do odgazowania drewna brzozowego i sosnowego. Kolejne piece zamierzano budować stopniowo $\mathrm{w}$ miarę wzrostu zapotrzebowania na gaz świetlny we Lwowie ${ }^{37}$. Uzyskany gaz odprowadzano żeliwną instalacją do chłodnic powietrznych, które miały na celu obniżenie jego temperatury. Na podstawie odszukanych projektów architektonicznych można przypuszczać, że ustawiono je w budynku odsiarczalni (zob. rys. 1). Zrezygnowano tym samym z osobnego budynku aparatowni, służącego na ich pomieszczenie, a charakterystycznego dla dużych kompleksów produkcji gazu. Uchodzący z chłodnic gaz poddawany był następnie procesom wymywania zeń amoniaku w płuczkach amoniakalnych i oczyszczania z siarkowodoru w skrzyniach odsiarczalnych. W wyniku schładzania z gazu wytrącały się smoła pogazowa i woda amoniakalna, które były zlewane do okrągłych zbiorników (tzw. dołów), wymurowanych w ziemi od północnej strony budynku odsiarczalni. Następnie gaz trafiał do znajdującego się w oddaleniu, tuż przy ul. Źródlanej, obudowanego i zadaszonego zbiornika mokrego (Gasometer) o pojemości $1661 \mathrm{~m}^{3}$. Oprócz piecowni (wraz z przybudówką destylarni wody amoniakalnej, dostawioną w 1874 r.) i odsiarczalni na parceli zakładu wystawiono dwupiętrowy budynek mieszkalno-administracyjny i niewielki parterowy budynek mieszczący warsztaty i kuźnię (zob. rys. 1) ${ }^{38}$.

${ }^{36}$ Projekty zabudowy kompleksu gazowni opracowano w marcu 1857 r. w Dessau, na ich podstawie 3 XII $1857 \mathrm{r}$. lwowski magistrat udzielił DCGG pozwolenia na budowę.

37 A. Teodorowicz, O rozwoju gazowni we Lwowie, „Przegląd Gazowniczy. Organ Zrzeszenia Gazowników Polskich w Warszawie” 1, 1921, nr 1-2, s. 3-4.

${ }^{38}$ DALO, Zarząd Miejski król. stoł. miasta Lwowa (dalej: f. 2), op. 1, sp. 2101, Betriebs Gebäude für die Gas Anstalt zu Lemberg, Dessau, 16 III 1857 r., k. 138; por.: A. Teodorowicz, dz. cyt., s. 4; R. Riedl, Urzadzenia i ruch gazowni, tłum. L. Obidowicz, J. Czaplicka, Warszawa 1952, s. 139-141, 150-158, 206-208; J. Pasnykiewicz, Rozwój technologii produkcji gazu węglowego, w: Historia gazownictwa polskiego. Od połowy XIX wieku po rok 2000, Łódź 2002, s. 99; M. Urbaniak, Miejskie zakłady przemysłowe Wielkiego Księstwa Poznańskiego: gazownie, t. 1: Zarys dziejów, Łódź 2011, s. $123,129$. 


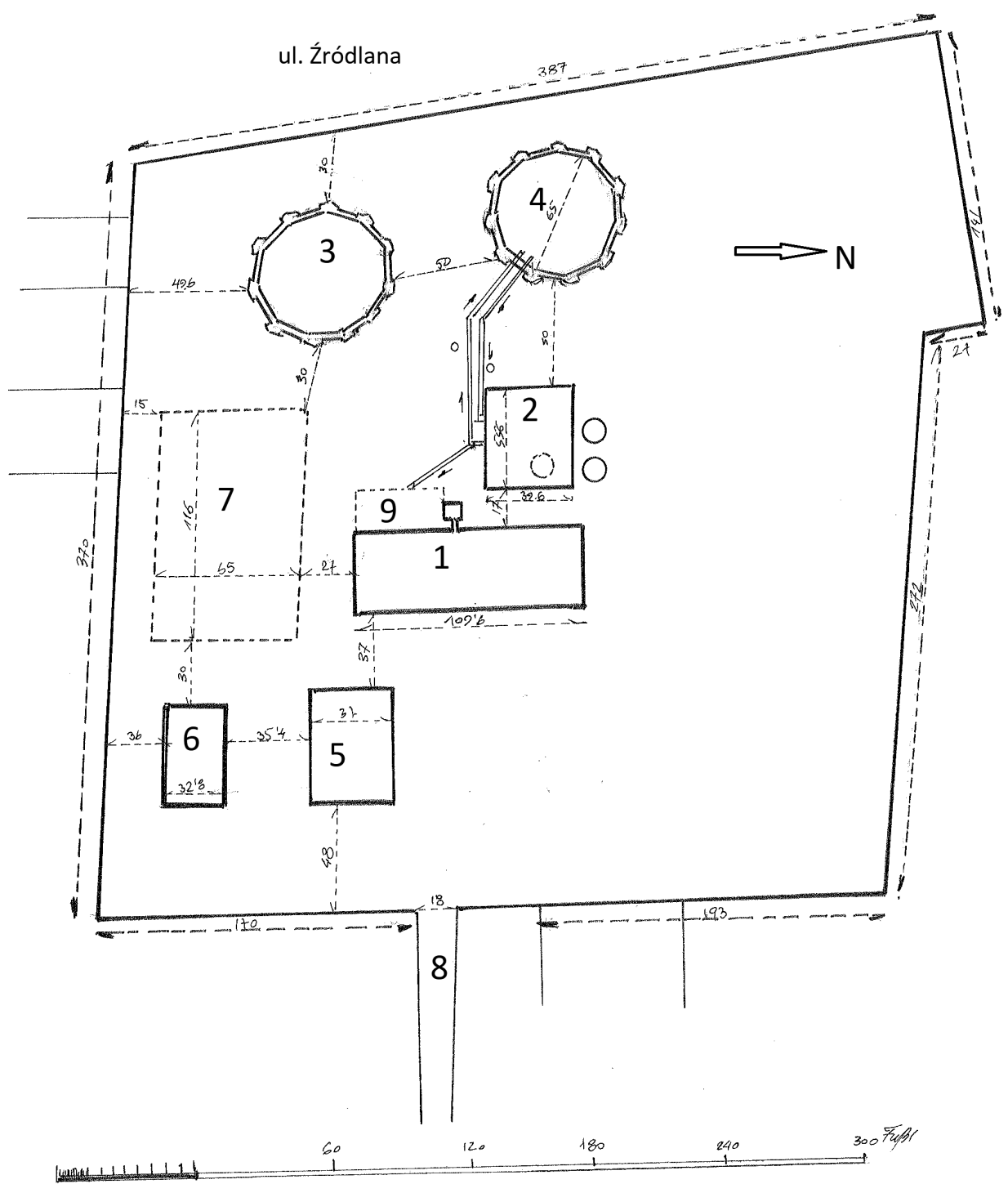

Rysunek 1. Usytuowanie lwowskiej gazowni według projektu z 1857 r.

Legenda: 1 - budynek piecowni, 2 - budynek odsiarczalni, 3 - zbiornik mokry wybudowany w $1858 \mathrm{r}$., 4 - zbiornik mokry wybudowany w 1877 r., 5 - dwupiętrowy budynek administracyjny, 6 - kuźnia i warsztaty, 7 - utwardzony plac do składowania surowca, 8 - nowo wytyczona ul. Gazowa, 9 - przybudówka destylarni wody amoniakalnej z $1874 \mathrm{r}$.

Źródło: DALO, f. 2, op. 1, sp. 2102, k. 118. 
W trzeciej ćwierci XIX w. drewno było nietypowym, a zarazem archaicznym surowcem poddawanym odgazowywaniu. Jego wyłączne użycie w lwowskiej gazowni, podobnie jak choćby w gazowniach w Wilnie i Temeszwarze, wynikało z ograniczonych możliwości transportu węgla. Nadmieńmy, że kolej doprowadzono do Lwowa w 1861 r., a transport węgla spławnymi rzekami również nie wchodził w grę. Stąd drewno pozostawało najtańszym i najbardziej dostępnym na miejscu surowcem do produkcji gazu. Dopiero w 1869 r. rozpoczęto odgazowywanie węgla dostarczanego koleja z Kopalni Królowa Luiza w Zabrzu. Rok później w ogóle zaprzestano używania drewna, które po odgazowaniu nadmiernie zanieczyszczało retorty osadzającym się na nich grafitem, co inwestor uznał za istotny mankament produkcji gazu we Lwowie ${ }^{39}$.

Rozbudowa gazowni miała miejsce w końcu lat 70. XIX w. Polegała na wymurowaniu w piecowni kolejnych sześciu pieców poziomoretortowych, w których można było uzyskiwać większe ilości gazu. W związku z tym wzniesiono drugi komin przemysłowy, który umożliwiał odprowadzenie większej ilości spalin z palenisk pieców. Zwiększenie produkcji gazu wymagało także rozbudowy instalacji schładzajacej (chłodnice wodne) i oczyszczającej gaz surowy (płuczki amoniakalne i skrzynie odsiarczalne ${ }^{40}$. Konieczne było także wykonanie drugiego zbiornika mokrego, zdolnego pomieścić $2327 \mathrm{~m}^{3}$ produkowanego gazu. Tym razem dzwonu zbiornika nie obudowano, co związane było z zastosowaniem systemu ogrzewania wody wypełniajacej jego basen w okresie zimy za pomoca kotłów parowych, ustawionych przy baterii pieców ${ }^{41}$.

W latach 80. XIX w. dessauska spółka nie rozbudowała gazowni, gdyż władze samorządowe Lwowa zdecydowały się na jej przejęcie, co z kolei nie motywowało do podejmowania poważniejszych inwestycji. Przełom nastapił w maju 1891 r., kiedy to na wniosek dyrektora gazowni Konrada Vossa miasto zdecydowano się na podstawie prowadzonych pertraktacji partycypować w połowie kosztów rozbudowy i modernizacji zakładu. Wniosek uzyskał poparcie radnych, mających na względzie

${ }^{39}$ Fünfehnter Geschäftsbericht des Directoriums der Deutsche Continental Gas-Gesellschaft. Vorgetragen in der 15. General-Versammlung am 12. März 1870, „Journal für Gasbeleuchtung und Wasserversorgung" 13, 1870, nr 4, s. 251.

${ }^{40}$ DALO, f. 2, op. 1, sp. 2101, Dokumentacja Miejskiego Urzędu Budowniczego w sprawie wydania pozwolenia na budowę z 27 V 1877 r., k. 29; A. Teodorowicz, dz. cyt., s. 4.

${ }^{41}$ DALO, f. 2, op. 1, sp. 2101, Dokumentacja Miejskiego Urzędu Budowniczego w sprawie wydania pozwolenia na budowę z 27 IV 1877 r., k. 24-26v, wraz z przedłożonym projektem technicznym: tamże, Gasometer, Dessau, 8 IV 1877 r., k. 120, 136; por. R. Riedl, Urzadzenia i ruch gazowni..., s. 268. 
to, że za osiem lat miasto miało przejacć na własność gazownię w stanie nadającym się do produkcji gazu ${ }^{42}$. W ramach prowadzonej przebudowy zlikwidowano dwa najstarsze piece rusztowe. Na ich miejscu wystawiono baterię trzech pieców półgeneratorowych systemu Hasse-Vacherot, w których zamurowano ceramiczne retorty wyprodukowane przez Szczecińską Fabrykę Szamotu S.A., przedtem Dider (Stettiner Chamotte-Fabrik A.-G., vormals Dider). Zastosowano zatem bardziej wydajne ogrzewanie pieców za pomocą zewnętrznego, głębszego paleniska, przystosowanego do opalania koksem z rozbudowanym systemem obiegu spalin wewnatrz pieca, co pozwalało na zastosowanie retort o większej pojemności niż dotychczas używane ${ }^{43}$. Doszło wówczas do wymiany i montażu nowych chłodnic i płuczek amoniakalnych. Zakupiono ponadto inne, bliżej nieokreślone „aparaty” ${ }^{44}$.

Po przejęciu gazowni przez gminę miasta Lwowa okazało się, że jej możliwości produkcyjne $\left(2 \mathrm{mln}^{3}\right.$ gazu rocznie) sa za małe $\mathrm{w}$ stosunku do stale rosnacego popytu na gaz. Z kapitału pozyskanego ze wspomnianej wcześniej emisji obligacji komunalnych postanowiono przeznaczyć 250 tys. guldenów na modernizacje gazowni ${ }^{45}$. W $1900 \mathrm{r}$. rozbudowano piecownię celem pomieszczenia kolejnych dwóch pieców 8-retortowych systemu Hasse-Vacherot. Zatem łącznie w piecowni używano dwóch baterii dziewięciu pieców, spośród których pięć ogrzewano półgeneratorami, a pozostałe cztery były konstrukcjami starego typu (z 1877 r.). We wszystkich 72 retortach można było pozyskać dziennie 15-18 tys. $\mathrm{m}^{3}$ gazu (3500 tys. $\mathrm{m}^{3}$ rocznie). Zwiększenie ilości produkowanego gazu zmuszało do zwiększenia objętości zbiorników mokrych. Należy przypuszczać, że modernizacja tych obiektów przeprowadzona w 1902 r. polegała na rozebraniu obudowy zbiornika z 1858 r. i następnie wykonaniu dodatkowych dzwonów, w które włożono dzwony dotychczas używane. Połączono je zamknięciem wodnym teleskopowo. Zabieg ten prawie dwukrotnie zwiększył objętość magazynu na gaz ${ }^{46}$.

${ }^{42}$ DALO, f. 3, op. 1, sp. 2961, K. Voss do magistratu miasta Lwowa, Lwów, 20 IV 1891, k. 68-69; DALO, f. 3, op. 1, sp. 3858, Protokół spisany w skutek komisji odbytej 6 VII 1891 przez ankietę wybraną uchwałą III sekcji rady miejskiej z 2 VI 1891 r., k. 2.

${ }^{43} \mathrm{O}$ sposobach udoskonalenia opalania pieców za pomoca generatorów zob.: Körting, dz. cyt., s. 186-191; M. Urbaniak, dz. cyt., s. 125.

${ }_{44}$ DALO, f. 3, op. 1, sp. 3858, Protokoły posiedzeń komisji gazowej i korespondencja z dyrekcją Miejskiego Zakładu Gazowego, k. 1-12v; A. Teodorowicz, dz. cyt., s. 5.

${ }^{45}$ Sprawozdanie prezydenta król. stot. miasta Lwowa [E. Mochnackiego] z trzechletniej czynności reprezentacji miejskiej i magistratu (1893, 1894 i 1895), Lwów 1896, s. 3.

${ }^{46}$ Sprawozdanie Komisji Gazowej $z$ administracji gazowni za czas od 1 stycznia do 31 grudnia 1900, Lwów 1901, s. 3, 7. 
Wobec stale zwiększającego się zapotrzebowania na gaz we Lwowie konieczna okazała się znacznie poważniejsza rozbudowa i modernizacja gazowni. Aby odpowiednio przygotować się do realizacji powziętego zamiaru, nowy dyrektor zakładu gazowego - inż. Adam Teodorowicz (1863-1921) - odbył w latach 1899-1903 podróże służbowe celem zapoznania się z najnowszymi technologiami produkowania gazu, stosowanymi w miastach austro-węgierskich i niemieckich. Zają się także szczegółowym zgłębianiem takiej problematyki, w wyniku czego powstało opracowanie, w którym postulował pozyskiwanie gazu z dwóch rodzajów paliw - węgla i ropy naftowej. Wskazywał następnie na konieczność wykonania zupełnie nowej instalacji do oczyszczania gazu oraz trzeciego zbiornika mokrego, zdolnego magazynować 10 tys. $\mathrm{m}^{3}$ gazu ${ }^{47}$.

Koszty tych inwestycji szacowano na ponad milion koron i zamierzano je pokryć ze wspomnianej wyżej emisji obligacji komunalnych, powiększonej w 1900 r. do sumy ponad 14 mln guldenów. Radni zaakceptowali ten projekt na posiedzeniach rady miejskiej 4 i $18 \mathrm{~V} 1905 \mathrm{r}^{48}$ Na przełomie 1905 i 1906 r. komisja gazowa rozstrzygnęła, którym oferentom należy zlecić wykonanie poszczególnych instalacji i urządzeń ${ }^{49}$. Trzeba zauważyć, że na etapie rozstrzygania przetargów starano się zlecać wykonanie planowanych prac przedsiębiorstwom galicyjskim. Kiedy firmy krajowe nie były w stanie podołać wykonaniu zbyt skomplikowanych urządzeń, wówczas decydowano się na zaakceptowanie ofert renomowanych producentów spoza terytorium kraju.

Z dokumentacji Miejskiego Urzędu Budowniczego wynika, że w drugiej połowie 1905 r. robotnicy lwowskiego przedsiębiorstwa budowlanego Alfreda i Kazimierza Kamienobrodzkich wznosili budynek przeznaczony na pomieszczenie instalacji do produkcji gazu wodnego nawęglanego olejami naftowymi (zob. rys. 2) ${ }^{50}$. Składał się on z wysokiej na dwie kondygnacje sali aparatów, w której ustawiono gazogenerator, karburator

${ }^{47}$ DALO, f. 599, op. 1, sp. 5, Sprawozdanie w sprawie powiększenia gazowni miejskiej, oprac. A. Teodorowicz, Lwów, 22 IV 1905 r., k. 3-9; A. Teodorowicz, dz. cyt., s. 8. Okoliczności obsadzenia posady dyrektora zakładu gazowego zob. Gazownia miejska, „Gazeta Techniczna. Dwutygodnik Społeczno-Techniczny we Lwowie” 1, 1898, nr 9, s. 89; W sprawie gazowni miejskiej, „Słowo Polskie” 28 V 1898, s. 3.

${ }^{48}$ DALO, f. 3, op. 1, sp. 4980, Wniosek komisji gazowej, Lwów, 28 IV 1905 r., k. 1-7v; DALO, f. 3, op. 1, sp. 5820, Sprawozdanie w sprawie powiększenia gazowni miejskiej we Lwowie, oprac. A. Teodorowicz, Lwów, 26 VI 1913 r., k. 104.

${ }_{49}$ Por. DALO, f. 3, op. 1, sp. 5104, Protokół spisany z powodu otwierania ofert na dostawę zbiornika gazowego o pojemności 10000 m³, Lwów, 7 II 1906 r., k. 6-10 v.

${ }^{50}$ Od $17 \mathrm{~V} 1905 \mathrm{r}$. wymienieni przedsiębiorcy pobierali z kasy miejskiej zaliczki na prowadzenie budowy; DALO, f. 599, op. 1, sp. 7, k. 43-61v. 


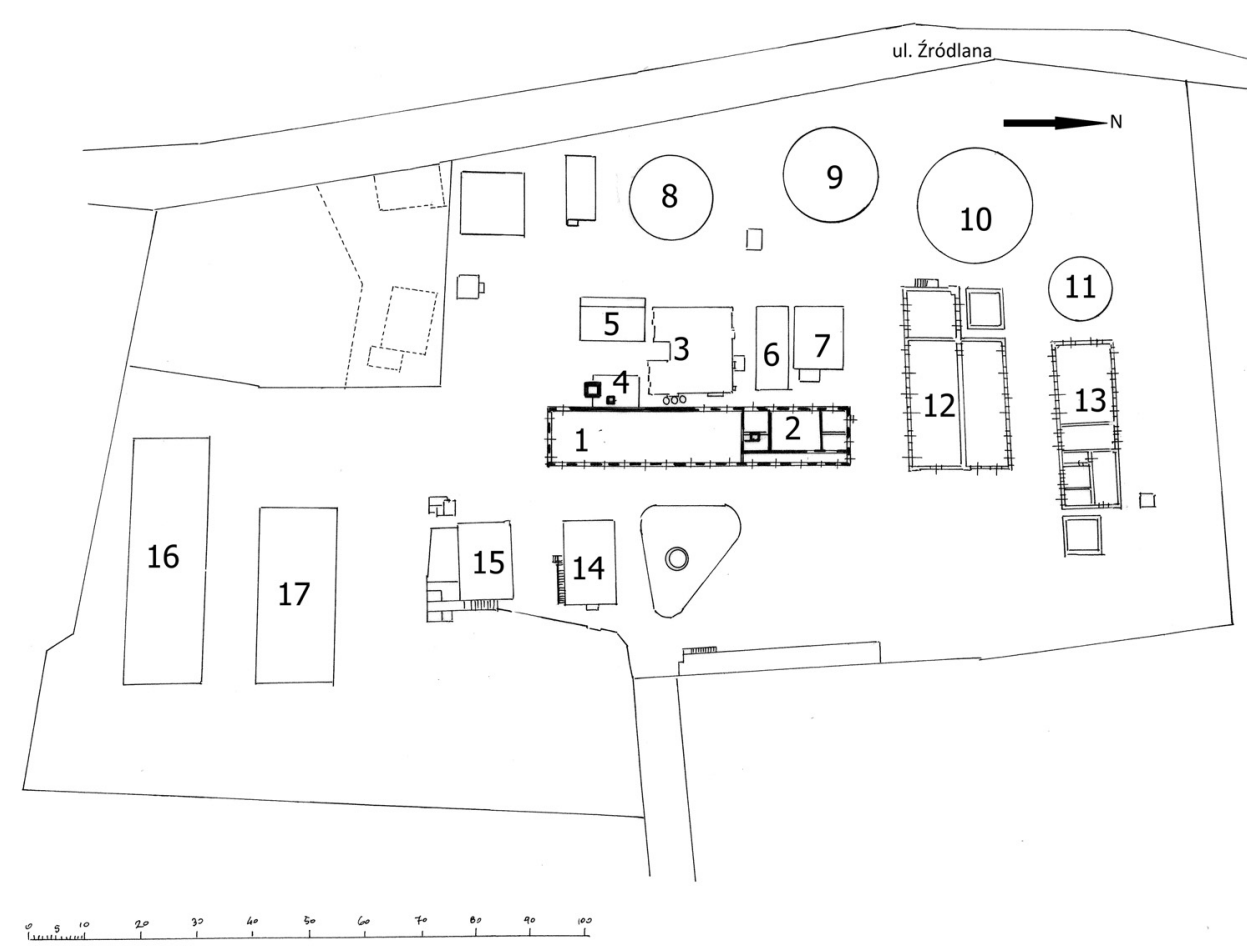

Rysunek 2. Usytuowanie lwowskiej gazowni według projektu z 1905 r.

Legenda: 1 - budynek piecowni, 2 - przybudówka kotłowni parowej, 3 - budynek odsiarczalni, 4 - przybudówka destylarni wody amoniakalnej z 1874 r., 5 - budynek regeneracji żelaznej rudy darniowej, 6 i 7 - podziemne baseny na smołę pogazową i wodę amoniakalną, 8 - zbiornik mokry z 1858 r. (zmodernizowany w 1902 r.), 9 - zbiornik mokry z 1877 r. (zmodernizowany w 1902 r.), 10 - zbiornik mokry wybudowany w latach 1906-1907, 11 - zbiornik mokry gazu wodnego nawęglanego, 12 - budynek odsiarczalni wybudowany w 1914 r., 13 - fabryka gazu wodnego nawęglanego wybudowana w latach 1905-1906, 14 - budynek administracyjny z 1857 r., 15 - budynek dla pracowników zakładu (dawna kuźnia i warsztaty), 16 i 17 - drewniane szopy do magazynowania węgla.

Źródło: DALO, f. 3, op. 1, sp. 4980, k. 9v-10.

i przegrzewacz oraz znajdujące się $\mathrm{w}$ dalszej kolejności chłodnicę wodna, płuczkę wieżową (skruber) i odsmalacz systemu Pelouze. Przewidziano także wolne miejsce na zamontowanie urządzeń $\mathrm{w}$ analogicznym układzie jak opisane, co nastapiło w 1909 r. Kolejnym pomieszczeniem była sala maszyn, w której zamontowano dwie maszyny parowe, każda o sile $6 \mathrm{KM}$, stanowiące napęd dla pomp, ssaków i odsmalaczy. Nad tym pomieszczeniem znajdowały się napełniane elewatorem leje zasypowe na koks, którym za pomoca przesuwanej po szynach kolebie napełniano od góry gazogenerator. W dalszej kolejności znajdowały się pomieszczenia dla pracowników oraz wystawiona od wschodu parterowa 
przybudówka mieszcząca kotłownię parowa. Ustawiono w niej dwa kotły parowe, z palenisk których dym odprowadzano wysokim na $36 \mathrm{~m}$ kominem przemysłowym ${ }^{51}$.

Gaz wodny wytwarzano w wyniku prażenia koksu w gazogeneratorze systemu Humphrey \& Glasgow, do którego w końcowym etapie jego odgazowania wdmuchiwano za pomocą wentylatorów parę wodna. Uzyskany w ten sposób gaz wodny kierowano do karburatora. W jego wnętrzu wypełnionym cegłami szamotowymi gaz wodny poddawany był w wysokiej temperaturze procesowi nawęglania - polegającemu na wejściu w reakcję z gazem olejnym. Uzyskiwano go z odpadów, jakimi były ciężkie oleje naftowe pozostałe po destylacji ropy naftowej, a które dolewano do karburatora. Sprowadzano je z rafinerii drohobyckich Zachariasza Händla i Salomona Kreppela. Następnie mieszaninę gazów poddawano schłodzeniu i oczyszczaniu. Wyprodukowany w opisany sposób gaz miał tę zaletę, że w procesie spalania dawał przy o połowę mniejszych ilościach produktu tę samą jasność światła jak w przypadku gazu węglowego. Koszty produkcji obniżała możliwość zaopatrywania gazowni w stosunkowo tanie oleje naftowe ${ }^{52}$. Wadą tej technologii był fakt, że wymagała znacznych nakładów finansowych w wykonanie opisanych urządzeń, lecz w zamian uzyskiwano gaz lepszej jakości, zużywając przy tym zalegajacy koks, będący odpadem po produkcji gazu węglowego. Gaz wodny nawęglony przechowywano w niewielkim zbiorniku mokrym $\left(500 \mathrm{~m}^{3}\right)$, znajdującym się tuż za budynkiem, w którym go produkowano (planowano produkcje do maksimum $7500 \mathrm{~m}^{3}$ dziennie ${ }^{53}$. Stąd zasysany był do budynku odsiarczalni, w której poddawany był procesom oczyszczania z siarkowodoru i następnie mieszania z gazem węglowym. Dopiero taka mieszanina była tłoczona do zbiorników mokrych, a stamtąd do gazociagów miejskich. Opisane urządzenia do produkcji gazu wodnego nawęglonego wykonano wiosną i latem 1906 r. pod nadzorem inżynierów wiedeńskiego zakładu, należącego do

${ }^{51}$ DALO, f. 2, op. 1, sp. 2101, Urządzenia fabryczne do wyrobu gazu wodno-naftowego, k. 151, 122, 125; por.: J. Bułat, Księga informacyjna król. stot. miasta Lwowa i czterech południowo-wschodnich województw Rzeczypospolitej Polskiej a to: lwowskiego, stanistawowskiego, tarnopolskiego $i$ wotyńskiego, Lwów 1927, s. 20b; J. Pasnykiewicz, dz. cyt., s. 115-123.

${ }^{52}$ R. Załoziecki, Użytkowanie ropy dla karburowania gazu, „Nafta. Organ Krajowego Towarzystwa Naftowego" 15, 1907, nr 16, s. 246; por. J. Körting, dz. cyt., s. 221-222.

${ }_{53}$ Zbiornik mokry został wykonany w końcu 1905 r.; zob. DALO, f. 599, op. 1, sp. 7, Rachunek za wykonanie robót przy zbiorniku gazu (małym) wodnego w gazowni miejskiej we Lwowie, b.d., k. 5-7. 
berlińskiego koncernu Juliusa Pintscha (Julius Pintsch A.-G.), a próbne uruchomienie produkcji miało miejsce zimą $1906 \mathrm{r}^{54}$

Równocześnie z realizacją opisanej wyżej inwestycji dokonano rozbudowy i modernizacji odsiarczalni. Wykonanie dodatkowych chłodnic wodnych, płuczek amoniakalnych, skrzyń odsiarczalnych i mechanizmu nowego zegara stacyjnego zlecono konsorcjum Galicyjskiego Towarzystwa Akcyjnego Budowy Wagonów i Maszyn z Sanoka i Berlińsko-Anhalckiej Fabryki Maszyn S.A. (Berlin-Anhaltische Maschinenfabrik A.-G. - BAMAG) ${ }^{55}$. Następnie zdecydowano zlecić Fabryce Maszyn L. Zieleniewski S.A. z Krakowa budowę trzeciego zbiornika mokrego o objętości 10 tys. $\mathrm{m}^{3}$. Komisja gazowa $\mathrm{w}$ ponownie zorganizowanym przetargu - wobec pojawiających się wątpliwości fachowców - uznała przedsiębiorstwo Zieleniewskiego za wiarygodnego wytwórcę, który zrealizował podobne zlecenie dla gazowni miejskiej w Krakowie ${ }^{56}$. Konstrukcja tegoż zbiornika, wykonywana od czerwca 1906 r., składała się z dwóch dzwonów - dolnego i górnego połączonych teleskopowo w ten sposób, że jeden mógł wysuwać się ponad drugi w miarę napełniania wnętrza gazem ${ }^{57}$.

W 1909 r. dokonano kolejnej rozbudowy i modernizacji piecowni. Polegała ona na likwidacji czterech pieców z 1877 r. i wystawieniu pięciu pieców 8-retortowych półgeneratorowych oraz trzech pieców 9-retortowych o pełnych generatorach. Zdecydowano także o wyposażeniu wszystkich pieców w system mechanicznego załadunku retort oraz ich opróżniania z koksu bezpośrednio do rynny z wodą i taśmociagiem

${ }^{54}$ DALO, f. 3, op. 1, sp. 5104, Pisma dyrekcji gazowni w sprawie wypłaty wynagrodzenia za wykonane prace, k. 11-14. Dokładny opis technologii produkcji gazu wodnego nawęglonego zob. DALO, f. 599, op. 1, sp. 6, Opis projektowanych urządzeń fabrycznych w gazowni miejskiej we Lwowie, oprac. A. Teodorowicz, [1905/1906 r.], k. 2-4; por. R. Riedl, Urzadzenia $i$ ruch gazowni..., s. 99-106, 227-228, 233-235; J. Körting, dz. cyt., s. 202-210, zob. zwł. na s. 209-210 opis instalacji skonstruowanej przez Alexandra Crombie Humphreysa z 1890 r.

55 DALO, f. 3, op. 1, sp. 4980, Wniosek komisji gazowej, Lwów, 28 VI 1905 r., k. 5; DALO, f. 3, op. 1, sp. 5104, A. Teodorowicz do III departamentu magistratu, Lwów, 23 III 1906 r., k. 11.

${ }^{56}$ Budowa zbiornika na $10000 \mathrm{~m}^{3}$ użytecznej pojemności gazu w miejskiej gazowni $w$ Krakowie, „Czasopismo Techniczne” (Lwów) 20, 1902, nr 14-16, s. 194-196, 207-211.

${ }^{57}$ Fotografię wyobrażająca rzut i przekrój tego zbiornika mokrego zob. Archiwum Polskiej Akademii Nauk w Warszawie, III-123, Materiały rodziny Zieleniewskich, sygn. 10, Zbiornik teleskopowy wolnostojacy na około $10000 \mathrm{~m}^{3}$ gazu świetlnego 1:50, z biura konstrukcyjnego Fabryki Maszyn L. Zieleniewski, Kraków [1905/1906 r.], fot. 35; DALO, f. 599, op. 1, sp. 7, Rachunek za wykonany fundament zbiornika gazowego na $10000 \mathrm{~m}^{3} \mathrm{w}$ zakładzie gazowni miejskiej, k. 18-20; DALO, f. 3, op. 1, sp. 5104, A. Teodorowicz do III departamentu magistratu, Lwów, 17 X 1906 r., k. 16. 
transportującym (system Brouvera). W końcu 1909 r. od wschodniej strony budynku piecowni ustawiono żelazny pojemnik na $80 \mathrm{~m}^{3}$ węgla wraz z dwoma elewatorami, które transportowały surowiec na urządzenia wrzutowe zamontowane wewnatrz piecowni ${ }^{58}$. W ten sposób ograniczono pracę ludzką w szczególnie niezdrowych warunkach, jakimi było zapylone i zadymione wnętrze tego budynku. Oszczędzono nie tylko zdrowie robotników, ale także fundusze przeznaczone na zatrudnianie piecowych, którzy zajmowali się ręcznym załadunkiem retort węglem i wygarnianiem po jego odgazowaniu rozżarzonego koksu.

Kolejna faza rozbudowy gazowni przypada na lata poprzedzajace wybuch I wojny światowej. Inwestycje te były możliwe dzięki przeznaczeniu części środków w kwocie 2 mln koron (pochodzących z kolejnej emisji obligacji komunalnych) na zakup gruntów przylegających bezpośrednio do parceli zakładu gazowego (zakupy działek przy ul. Źródlanej w 1910 i ul. Gazowej w 1912 r.) oraz gruntu przy drodze żółkiewskiej pod budowę nowej gazowni - tuż przy zabudowaniach Centralnej Rzeźni i Targowisk Miejskich na Gabrielówce ${ }^{59}$. Na tychże działkach - w myśl uchwał rady miejskiej z 17 i 27 VII 1913 r. - planowano wybudowanie nowych piecowni wraz z urządzeniami do schładzania, czyszczenia i magazynowania gazu. Lokalizacja nowej gazowni przy trakcie żółkiewskim, której budowę planowano rozpoczać w 1915 r., była korzystna z tego względu, że parcela ta miała dostęp do bocznicy kolejowej. Brak skomunikowania dotychczas użytkowanej gazowni z siecią kolejową był istotnym mankamentem, trzeba było bowiem ponosić dodatkowe koszty transportu węgla $\mathrm{z}$ lwowskiego dworca kolejowego ${ }^{60}$.

W stosownym opracowaniu przedłożonym w magistracie dyrektor Teodorowicz zalecał wybudowanie piecowni pionoworetortowych systemu Glover-West, zarówno w dotychczas użytkowanym zakładzie, jak i tym mającym powstać przy trakcie żółkiewskim ${ }^{61}$. Z zachowanej dokumentacji wynika, że 16 XI 1913 r. Urząd Budowniczy zatwierdził projekt budowy nowej piecowni o ośmiu retortach pionowych ${ }^{62}$. Ładowanie

${ }^{58}$ Komisja Gazowa. Posiedzenie z dnia 25 maja 1908, „Dziennik Lwowski. Organ urzędowy gminy król. stoł. miasta Lwowa" 3, 1908, nr 11, s. 219; Komisja Gazowa. Posiedzenie dnia 7 lipca 1909, „Dziennik Lwowski. Organ urzędowy gminy król. stoł. miasta Lwowa” 4, 1909, nr 14, s. 345; Gazownia miejska we Lwowie, „Przegląd Techniczny" 48, 1910, nr 43, s. 528; J. Bułat, dz. cyt., s. 20 b.

${ }^{59}$ DALO, f. 3, op. 1, sp. 5820, Sprawozdanie w sprawie powiększenia gazowni miejskiej we Lwowie, oprac. A. Teodorowicz, Lwów, 26 VI 1913 r., k. 104-105.

60 Tamże, k. 105-106.

61 Tamże, k. 107-108.

${ }^{62}$ DALO, f. 2, op. 1, sp. 2101, Piecownia nr 2 dla wyrobu gazu węglowego z piecami o retortach pionowych systemu Glover-West, k. 142. 
retort węglem w tym typie pieców odbywa się z góry. W sposób ciagły węgiel przechodził przez ceramiczne retorty, w których był odgazowywany. Ruch węgla odbywał się w dół, wówczas pod wpływem wysokiej temperatury (piec ogrzewany był gazem pochodzacym z wymurowanego $\mathrm{z}$ boku pieca generatora), węgiel poddany prażeniu przemieniał się $\mathrm{w}$ dolnej części retort w koks, który poddawany był schłodzeniu parą wodna. W ten sposób powstawał gaz wodny, a schłodzony koks był wybierany pod spodem retort za pomoca specjalnego zamknięcia ${ }^{63}$. Ta zaawansowana technologicznie piecownia umożliwiała w krótkim czasie produkcję znacznych ilości gazu, a także stopniowe wyłączanie z eksploatacji tej używanej dotychczas. Na początku 1914 r. przeprowadzono przetarg na dostawę urządzeń do nowej piecowni, aparatowni i odsiarczalni ${ }^{64}$. Inwestycje te zostały przerwane ze względu na wybuch wojny, a korzyści z ich realizacji miasto odniosło dopiero w okresie międzywojennym ${ }^{65}$. Wiosna 1914 r. udało się jedynie wystawić nowe budynki aparatowni i odsiarczalni. Ich wyposażenie $\mathrm{w}$ niezbędne instalacje i urządzenia $\mathrm{z}$ trudem zrealizowano dopiero w końcu 1917 r. na podstawie zawartych jeszcze przed wybuchem wojny kontraktów. Natomiast ostatecznie nie udało się zrealizować planów wybudowania drugiej gazowni na północnych przedmieściach Lwowa, przy drodze żółkiewskiej.

\section{Sieć gazociągów i zużycie gazu}

Na mocy zawartego w 1856 r. kontraktu DCGG zobowiązało się oświetlać gazem jedynie centrum miasta i główne ulice. Rozbudowa sieci gazowej miała następować stopniowo w porozumieniu z władzami miasta. Na podstawie tych postanowień kontraktu urzędnicy magistratu pertraktowali z dyrekcja gazowni, na których ulicach należy dokonać rozszerzenia gazociagów. W trakcie prowadzenia uzgodnień dyrekcja gazowni przedstawiała magistratowi szczegółowe kosztorysy na wykonanie planowanych prac, których koszty miasto powinno pokryć w połowie. Do końca lat 80. XIX w. ekspansja sieci gazowej na terytorium miasta zależała przede wszystkim od tego, czy w danym roku budżetowym urzędnikom magistratu udało się przeznaczyć jakieś sumy na

${ }^{63}$ DALO, f. 3, op. 1, sp. 5820, Sprawozdanie w sprawie powiększenia gazowni miejskiej we Lwowie, oprac. A. Teodorowicz, Lwów, 26 VI 1913 r., k. 107; A. Teodorowicz, dz. cyt., s. 9-10; R. Riedl, Urzqdzenia i ruch gazowni..., s. 165-169.

${ }_{64}$ DALO, f. 3, op. 1, sp. 5949, Dokumentacja przeprowadzonego przetargu, Lwów, 26 II 1914 r., k. 1-11.

65 J. Bułat, dz. cyt., s. 20b. 
oświetlenie miasta. Z dokumentacji wynika, że czasem sami właściciele nieruchomości domagali się wprowadzenia na poszczególnych ulicach oświetlenia gazowego. Argumentowali, że dzięki temu ulice będą częściej uczęszczane, a przy takich ulicach rozkwita handel, co jest bardzo korzystne nie tylko dla mieszkańców, ale również - jak podkreślano dla miasta, dzięki odprowadzanym podatkom.

Stosowne zapisy kontraktu z 1856 r. przewidywały, że rury doprowadzajace gaz powinni montować pracownicy gazowni pod kierownictwem biegłego w tym zakresie inżyniera. Montaż sieci gazowej mogły także wykonywać inne osoby, jednak pod warunkiem, że prace takie będa prowadzone pod nadzorem pracowników zakładu gazowego. Przy układaniu sieci stosowano odlewane rury żeliwne, które łączono na rękawy uszczelniane sznurami i zakuwane ołowiem. Rury o średnicach mniejszych niż $4 \mathrm{~cm}$ gwintowano i skręcano za pomoca odpowiednich nakładek. Przed doprowadzeniem ich do poszczególnych odbiorców montowano licznik, który miał za zadanie mierzyć zużycie gazu. Urządzenie to było własnościa zakładu gazowego, a odbiorcy ponosić musieli koszt jego dzierżawy od gazowni. We wnętrzach budynków instalacje wykonywali na koszt właścicieli zatrudniani przez nich ślusarze. Aby móc podjać się wykonania instalacji gazowej, należało uzyskać od zakładu gazowego specjalną koncesję. Wiadomo, że na zlecenie magistratu taką instalację w budynku ratusza wykonał Zygmunt Moser ${ }^{66}$.

Trzeba zauważyć, że sieć gazowa była rozbudowywana przede wszystkim po to, aby umożliwić dostarczenie gazu dla oświetlania ulic, dopiero równocześnie, bądź nieco później, do takiej sieci byli podłączani prywatni odbiorcy. Było to typowe postępowanie w przypadku instalowania sieci gazowych, ponieważ oświetlanie ulic gazem jeszcze w połowie XIX w. postrzegane było jako „objaw nowoczesności”. Światło emitowane podczas spalania gazu wydawało się jaśniejsze niż to uzyskiwane ze spalania oliwy. Tym samym taki sposób oświetlania był uznawany za substytut światła słonecznego ${ }^{67}$. Niemniej do końca XIX stulecia znacząco tańszym od gazu paliwem była nafta. $Z$ tego powodu latarnie naftowe do początku XX w. zdominowały oświetlenie publiczne

${ }_{66}$ DALO, f. 3, op. 1, sp. 2730, Sprawozdanie o urządzeniu oświetlenia gazowego w zabudowaniach, Lwów, 4 V 1872 r., k. 7-8v; tamże, Urządzenie oświetlenia gazowego w zabudowaniach, [1872 r.], k. 9-10v; DALO, f. 3, op. 1, sp. 5104, Regulamin dostawy gazu z gazowni miejskiej we Lwowie, Lwów, 17 XII 1906 r.., k. 17v-18. Przepisy określające zasady montażu instalacji gazowych zob. J.R. Kasperek, Zbiór ustaw i rozporzqdzeń administracyjnych $w$ Królestwie Galicji i Lodomerii $z$ Wielkim Księstwem Krakowskim obowiazujacych [...], t. 2, Lwów 1884, s. 1906.

${ }^{67}$ W. Schivelbusch, dz. cyt., s. 69-74. 
Lwowa. Przede wszystkim ustawiano je w bocznych ulicach i na przedmieściach, przeznaczając centrum miasta i główne ulice dla ustawienia latarniami gazowymi.

Dysponujemy szczegółową listą odbiorców produkowanego gazu z lat 1880-1881. Wynika z niej, że najwięcej gazu zużywały urzędy krajowe i miejskie oraz instytucje wyznaniowe i kulturalne. W Teatrze Skarbkowskim, w którym oprócz wystawiania dramatów wynajmowano sale na posiedzenia sejmu galicyjskiego, zamontowano aż trzy ujęcia gazu. Następnie spore ilości gazu zużywali: magistrat (w budynku ratusza), szkoły miejskie i komendy policji, Szkoła Politechniczna, synagogi, prokuratoria skarbu i inne siedziby urzędów (łącznie 23 odbiorców). W dalszej kolejności wykazu ujęto właścicieli sklepów, rzemieślników i przedsiębiorstw usługowych (30 odbiorców) oraz 303 odbiorców prywatnych ${ }^{68}$. Zważywszy, że liczba mieszkańców Lwowa w tym okresie wynosiła około 110 tys., wypada zauważyć, że na oświetlanie pomieszczeń gazem mogli sobie pozwolić jedynie najbardziej zamożni mieszkańcy miasta, inni zaś używali do oświetlania nafty. Dominująca pozycję w konsumpcji gazu miała gmina miasta Lwowa (na cele oświetlenia miasta) oraz urzędy państwowe, krajowe i miejskie. Taki stan rzeczy był typowy nie tylko dla Lwowa, ale dla większości europejskich i północnoamerykańskich miast. Wzrost liczby konsumentów gazu we Lwowie w siódmej i ósmej dekadzie XIX w. nie dorównał dynamice wzrostu konsumentów w miastach niemieckich, a także w Warszawie. Tendencja do znaczącego zwiększania się liczby prywatnych odbiorców gazu wystapiła dopiero pod koniec XIX w. Natomiast zjawisko ekspansji oświetlenia gazowego było skutkiem coraz większej konkurencji spółek gazowych, co prowadziło do potanienia produkowanego gazu. Tendencja ta była także efektem konkurowania oświetlenia gazowego z elektrycznym, co doprowadziło z kolei do wprowadzenia przez Carla Auera von Welsbacha (1858-1929) innowacyjnej metody uzyskiwania jaśniejszego światła przez zastosowanie żarzaceej się siatki wykonanej z tlenków rzadkich metali69.

Lwowskie ulice oświetlano latarniami, które emitowały światło w wyniku spalania w lampach gazu bądź nafty. Jak już wiemy, lampy gazowe winny emitować światło o sile 12, a naftowe 20-25 świec. Oprócz tego latarnie dzielono na wieczorne i całonocne. Te drugie oznaczone

${ }^{68}$ DALO, f. 3, op. 1, sp. 3168, Szczegółowy wykaz konsumentów gazu we Lwowie z podaniem cen za oświetlenie w r. 1880 i 1881, oprac. M. Dąbrowski, k. 109-123v.

69 R. Wowkonowicz, Postęy gazowego światta żarowego, „Czasopismo Techniczne” (Lwów) 26, 1908, nr 18 i 26, s. 273-278; H.M. Rose, Urban Gas and Electric Systems and Social Change 1900-1940, w: Technology and the Rise..., s. 230-232; M. Urbaniak, dz. cyt., s. 50-53. 
były kolorem czerwonym, a ich lampy paliły się aż do świtu. Latarnie wieczorne były gaszone o godzinie 23. Czas zapalania i gaszenia latarń określono w specjalnej tabeli, co związane było z dostosowaniem tych czynności do wschodów i zachodów słońca w danej porze roku ${ }^{70}$. Najstarsze odszukane informacje o ilości zamontowanych w mieście latarni posiadamy z czasu budowy gazowni w $1857 \mathrm{r}$. Wówczas po podpisaniu umowy przygotowano specjalny aneks, w którym zawarto szczegółowy ich wykaz na poszczególnych ulicach i placach. Na tej podstawie możemy przypuszczać, że w 1858 r. zamontowano we Lwowie 526 kandelabrów i latarni gazowych ${ }^{71}$. Odszukane wzmianki z $1881 \mathrm{r}$. informuja, że miasto oświetlano 705 latarniami gazowymi, spośród których całą noc paliły się 151. Większy udział w oświetleniu ulic miały tańsze w eksploatacji latarnie naftowe, których w wymienionym roku naliczono $984^{72}$. Kolejny wykaz informujacy o liczbie zamontowanych $\mathrm{w}$ mieście latarni posiadamy z 1895 r. Ulice Lwowa rozświetlało wówczas 829 latarni gazowych (w tym 216 nocnych) i 393 nowo zamontowanych latarni naftowych ${ }^{73}$. Liczba tych ostatnich wynosiła w 1898 r. 1008 (w tym 176 nocnych). Natomiast po 1900 r. liczba latarni gazowych w mieście wzrastała lawinowo, co spowodowane było dynamicznym procesem wymiany latarni naftowych na gazowe z palnikami Auera (zob. tab. $)^{74}$.

Trzeba zauważyć, że sieć gazociagów w mieście rozbudowywano powoli, gdyż w 1898 r. przejęto od dessauskiej spółki 854 latarni gazowych i 30 km gazociagów. Dopiero w latach 1899-1904, dzięki przeznaczeniu znacznych środków na inwestycje infrastrukturalne, zamontowano na ulicach Lwowa 957 nowych latarni i ułożono kolejne $47 \mathrm{~km}$ rur gazowych ${ }^{75}$. W tym czasie bardzo dynamicznie rosła konsumpcja gazu dostarczanego odbiorcom prywatnym (od $1108695 \mathrm{~m}^{3} \mathrm{w} 1893 \mathrm{r}$. do $2053910 \mathrm{~m}^{3} \mathrm{w} 1904 \mathrm{r}$.), co związane było ze spadkiem cen na gaz i rozbudowa sieci gazowej ${ }^{76}$. Kolejne znaczne rozszerzenia sieci gazowych miały miejsce po 1906 r., jak wynika z pobieranych przez zakład

${ }^{70}$ DALO, f. 3, op. 1, sp. 2730, Instrukcja dla kontroli publicznego oświetlenia tudzież wywozu nieczystości we Lwowie, Lwów, 9 II 1886 r., k. 80 v.

${ }^{71}$ DALO, f. 3, op. 1, sp. 1912, Verzeichnis, Lemberg, 15 I 1857 r., k. 73-74v.

${ }^{72}$ L. Aleksandrowicz, W. Górecki, O znaczniejszych robotach publicznych wykonanych $w$ mieście Lwowie w r. 1880, „Dźwignia. Organ Towarzystwa Ukończonych Techników we Lwowie" 6, 1882, s. 4-5.

${ }^{73}$ K. Ostaszewski-Barański, Poglą na działalność..., s. 178.

${ }^{74}$ Oświetlenie naftowe m. Lwowa, „Kurier Lwowski” 18 XII 1898, s. 2-3; E. Strasburger, dz. cyt., s. 260.

${ }^{75}$ DALO, f. 599, op. 1, sp. 5, Sprawozdanie w sprawie powiększenia gazowni miejskiej, oprac. A. Teodorowicz, Lwów, 22 IV 1905 r., k. 4.

${ }^{76}$ DALO, f. 3, op. 1, sp. 4980, Tabela graficzna spotrzebowania gazu, k. 12 . 
gazowy zaliczek i przedkładanych rachunków za położenie rur gazowych, wykonano wówczas dalsze kilometry sieci. Dążono przy tym do całkowitego wyeliminowania latarni z lampami naftowymi, co jednak nie nastapiło do wybuchu wojny (zob. tab. 2) ${ }^{77}$.

Urzędnicy magistratu, jak i sami radni - zwłaszcza ci delegowani do komisji gazowej - interesowali się aktualnymi technologiami produkcji i dostarczania gazu. To zainteresowanie niejako wymuszała konieczność racjonalnej oceny wniosków składanych w latach 70. XIX w. przez DCGG dotyczących propozycji zmian w zawartym kontrakcie gazowym. Pokłosiem zgłębiania tej problematyki była inicjatywa zamontowania w mieście nowego typu latarni - z palnikami systemu Friedricha Siemensa. Po analizie opinii biegłych inżynierów i przedłożonych przez zakład gazowy kosztorysów na posiedzeniu 23 X 1888 r. radni uchwalili, aby zamontować kosztowne latarnie (830 guldenów za sztukę) z lampami wymienionego systemu, które będą emitowały intensywne światło o sile ok. 250 świec $^{78}$. Tak silne światło miało umożliwiać odpowiednie oświetlanie największych i najbardziej uczęszczanych przez mieszkańców placów w Śródmieściu, tj. Gołuchowskich, Mariackiego, Halickiego i Bernardyńskiego ${ }^{79}$. Konstrukcja tych lamp polegała na ponownym doprowadzeniu do komory spalania części spalin. Dzięki temu podwyższano temperaturę spalania przy jednoczesnym zmniejszeniu zużycia gazu (o ok. $20-40 \%)^{80}$.

Kolejna innowacją zastosowaną na potrzeby publicznego oświetlenia były palniki gazowo-żarowe, skonstruowane w 1890 r. przez wiedeńskiego chemika, wspominanego już Auera. W latarniach z tego typu palnikami gaz zmieszany $\mathrm{z}$ powietrzem spalany był na siatce $\mathrm{z}$ dwutlenku toru i ceru (tzw. koszulka Auera). Ten element palnika rozgrzewał się do wysokiej temperatury, emitując jasne, intensywne światło oraz spalając przy tym o połowę mniej gazu niż dotychczas używane palniki nietoperzowe. Te właściwości palników gazowo-żarowych spowodowały, że od momentu wprowadzenia ich do sprzedaży było na nie bardzo duże zapotrzebowanie. Stąd też na 814 latarni oświetlających miasto w 1894 r. w 387 zdecydowano się wymienić palniki nietoperzowe

77 Tamże, Korespondencja dyrekcji Miejskiego Zakładu Gazowego z magistratem, k. $15-36$.

${ }^{78}$ DALO, f. 3, op. 1, sp. 3333, Kosztorys przedłożony przez dyrektora gazowni, [1888 r.], k. 14r-v.

79 Tamże, Wniosek III departamentu magistratu, Lwów, 20 XI 1888 r., k. 2-3; Urzqdzenia miejskie, „Czasopismo Techniczne” (Lwów) 7, 1889, nr 10, s. 75-76.

80 J. Szczepaniak, Palniki Fryderyka Siemensa, „Czasopismo Techniczne” (Lwów) 5, 1887, nr 9, s. 102-103. 
na koszulki Auera ${ }^{81}$. Po 1900 r. rozpoczał się proces wymiany palników nietoperzowych na koszulki auerowskie, tak że przed I wojną światowa we wszystkich latarniach gazowych zamontowano koszulki Auera. Od 1907 r. zaś gazownia produkowała gaz wodny nawęglany, który jeszcze bardziej poprawił ekonomikę spalania gazu w palnikach gazowo-żarowych.

Produkcja gazu od momentu uruchomienia zakładu w 1858 r. rosła od $143157 \mathrm{~m}^{3}$ do $958712 \mathrm{~m}^{3}$ gazu wyprodukowanego w $1877 \mathrm{r}$. Wzrost ten spowodowany był przede wszystkim stałym rozszerzaniem sieci gazociagów w Śródmieściu i na głównych ulicach. Tak duży wzrost był możliwy dzięki rozbudowie gazowni po $1877 \mathrm{r}$. Następnie roczna produkcja gazu w latach 1877-1890 ustabilizowała się w granicach $1 \mathrm{mln} \mathrm{m}^{3}$ (zob. tab. 1). W tym czasie DCGG uzależniało podjęcie poważniejszych inwestycji od zgody miasta na zrzeczenie się tytułu własności bądź znacznego przedłużenia możliwości administrowania zakładem gazowym. Kiedy tego nie udało się dokonać, dessauska spółka nie była zainteresowana rozbudowa i modernizacja gazowni. Dopiero po porozumieniu z samorządem miejskim w $1891 \mathrm{r}$. doszło do modernizacji gazowni, w wyniku której do $1898 \mathrm{r}$. zwiększono produkcję do $2 \mathrm{mln} \mathrm{m}^{3}$ gazu rocznie. Po przejęciu gazowni przez miasto nastapił gwałtowny wzrost produkcji, aż do wybuchu I wojny światowej, w $1912 \mathrm{r}$. przekroczono liczbę $7 \mathrm{mln} \mathrm{m}^{3}$ produkowanego gazu (zob. tab. 2). Tak gwałtowny wzrost wynikał zarówno z rozszerzenia sieci gazowej, jak i gwałtownego wzrostu liczby prywatnych odbiorców, którzy coraz bardziej byli zainteresowani konsumpcją coraz tańszego gazu, nie tylko do oświetlania pomieszczeń, ale także do ogrzewania i gotowania. Trzeba nadmienić, że zużycie gazu na ostatnie wymienione cele zaczęło stale wzrastać z $151370 \mathrm{~m}^{3} \mathrm{w} 1900 \mathrm{r}$. do $3115648 \mathrm{~m}^{3}$ gazu w $1913 \mathrm{r}$. A poziom zużycia gazu dla oświetlania pomieszczeń ustabilizował się, osiagając w 1910 r. maksymalną wartość $3229520 \mathrm{~m}^{3}$ gazu, po czym zaczą spadaćc ${ }^{82}$.

Przed I wojna światowa produkowany we Lwowie gaz stanowił główne źródło energii przeznaczanej na potrzeby oświetlania miasta i do użytku mieszkańców. Jednak od końca XIX w. używanie gazu do oświetlania stawało się anachronizmem. Zdawano sobie sprawę, że palniki

${ }^{81}$ Oświetlenie miasta Lwowa świattem Auera, „Gazeta Narodowa” 6 X 1894, s. 1. Szczegółowy opis technologii oświetlania palnikami gazowo-żarowymi Auera przedstawił: A. Teodorowicz, Z przemystu gazowego, „Czasopismo Techniczne” (Lwów) 14, 1896, nr 1, s. 10-12.

${ }^{82}$ Dane statystyczne pokazujące te tendencje opublikowano w: „Wiadomości Statystyczne o Mieście Lwowie” 12, 1910, s. 269; 14, 1914, s. 226-227; por. E. Strasburger, dz. cyt., s. 263. 
Tabela 1. Produkcja gazu i liczba używanych palników gazowych we Lwowie w latach $1858-1898$

\begin{tabular}{|c|c|c|}
\hline Lata & Produkcja gazu $\mathrm{w}^{3}$ & $\begin{array}{l}\text { Liczba zamontowanych } \\
\text { palników gazowych* } \\
\text { [liczba publicznych latarni } \\
\text { i kandelabrów gazowych] }\end{array}$ \\
\hline 1858 & 143157 & $2110[526]$ \\
\hline 1859 & 277174 & 2670 \\
\hline 1860 & 302000 & 3027 \\
\hline 1861 & 353394 & 3503 \\
\hline 1862 & 385000 & 4320 \\
\hline 1863 & 419151 & 4535 \\
\hline 1864 & 451196 & 4687 \\
\hline 1865 & 477899 & 4937 \\
\hline 1866 & 445036 & 5632 \\
\hline 1867 & 459043 & 6172 \\
\hline 1868 & 505384 & 6119 \\
\hline 1869 & 533936 & 6354 \\
\hline 1870 & 568779 & 7263 \\
\hline 1871 & 605571 & 7532 \\
\hline 1872 & 698151 & 8281 \\
\hline 1873 & 763959 & 8468 \\
\hline 1874 & 783285 & 8826 \\
\hline 1875 & 845420 & 9292 \\
\hline 1876 & 926109 & 10147 \\
\hline 1877 & 958711 & 10436 \\
\hline 1878 & 984806 & 10480 \\
\hline 1879 & 943107 & 11256 \\
\hline 1880 & 997912 & 11665 \\
\hline 1881 & 997111 & 12175 [705] \\
\hline 1882 & 951346 & 11607 \\
\hline 1883 & 973555 & 9068 \\
\hline 1884 & 943107 & 9261 \\
\hline 1885 & 1059049 & 9540 \\
\hline 1886 & 1029178 & 9062 \\
\hline 1887 & 1070461 & 9209 \\
\hline 1888 & 1049180 & 9481 \\
\hline 1889 & 993750 & 10169 \\
\hline 1890 & 1101380 & 10956 \\
\hline 1891 & 1231910 & b.d. \\
\hline
\end{tabular}




\begin{tabular}{|c|c|c|}
\hline 1892 & 1428540 & b.d. \\
\hline 1893 & 1627780 & b.d. \\
\hline 1894 & 1844520 & b.d. [814] \\
\hline 1895 & 1782590 & b.d. [829] \\
\hline 1896 & 1825520 & b.d. \\
\hline 1897 & 1988770 & b.d. \\
\hline 1898 & $1247590+889350^{* *}$ & b.d. [862] \\
\hline
\end{tabular}

Legenda: * liczba publicznych (miejskich) oraz zainstalowanych w pomieszczeniach palników gazowych (Flammen); ** wielkość produkcji gazu w 1898 r., po przejęciu gazowni przez gminę miasta Lwowa (po 1 IX 1898 r.); b.d. - brak danych.

Źródło: Produkcja gazu w lwowskiej gazowni oraz liczba używanych w mieście palników gazowych zostały podane w rocznych sprawozdaniach dyrekcji Niemieckiego Kontynentalnego Towarzystwa Gazowego w Dessau, publikowanych na łanach: „Journal für Gasbeleuchtung und Wasserversorgung” 1-40, 1858-1898; Archiwum Państwowe Obwodu Lwowskiego, f. 599, Miejski Zakład Gazowy we Lwowie, op. 1, sp. 5, Tabela graficzna ogólnego oddania gazu w latach 1858-1912, k. 16.

gazowe zużywaja duże ilości tlenu w pomieszczeniach zamkniętych oraz podnoszą temperaturę powietrza. Pomimo wprowadzenia innowacji w postaci palników żarowych Auera, oświetlenie gazowe zanieczyszczało pomieszczenia sadzami. Konserwacja sieci gazowych również wymagała istotnych nakładów. Ponadto gaz używany na masową skalę do oświetlania reprezentacyjnych budynków użyteczności publicznej powodował ryzyko wywołania pożaru bądź zatrucia ludzi. Uświadomiły to katastrofy takie jak eksplozje zbiorników mokrych czy pożary wzniecone w teatrach i operach ${ }^{83}$. Dlatego kiedy w latach 80. XIX w. pojawiła się możliwość używania konkurencyjnego źródła energii w postaci elektryczności, wówczas to ta technologia została uznana za „objaw nowoczesności”, podobnie jak oświetlenie gazowe w pierwszej połowie XIX w.

Wdrożenie technologii wytwarzania elektryczności dokonało się w stolicy Galicji tuż przed otwarciem Powszechnej Wystawy Krajowej w $1894 \mathrm{r}$. Wybudowano wówczas elektrownię dla zasilania sieci trakcyjnej tramwajów elektrycznych. Od 1900 r. elektryczności zaczęto używać do oświetlania nowo wzniesionego okazałego gmachu Teatru Miejskiego ${ }^{84}$. Tym samym światło elektryczne stanowiło swego rodzaju ekskluzywny i bardziej higieniczny sposób oświetlania reprezentacyjnych pomieszczeń. W 1901 r. słupy z elektrycznymi lampami łukowymi ustawiono na ul. Karola Ludwika, Wałach Hetmańskich oraz na placach

${ }^{83}$ W. Schivelbusch, dz. cyt., s. 40-47; J.B. Fressoz, The Gas Lighting Controversy. Technological Risk, Expertise and Regulation in Nineteenth-Century Paris and London, „Journal of Urban History” 33, 2007, nr 5, s. 729-755.

${ }^{84}$ J. Szuliński, Teatr Miejski we Lwowie, Warszawa 2002, s. 51. 
Tabela 2. Sieć gazociagów, produkcja gazu i dochody Miejskiego Zakładu Gazowego we Lwowie w latach 1898-1913

\begin{tabular}{|c|c|c|c|c|c|c|c|}
\hline 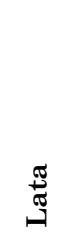 & 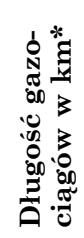 & 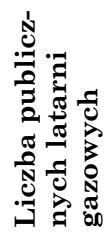 & 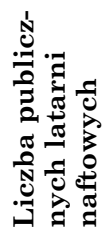 & 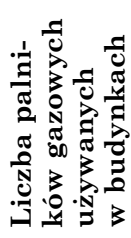 & 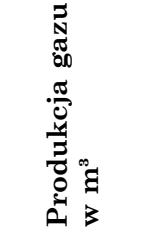 & 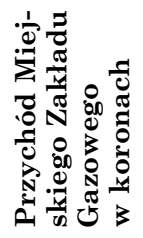 & 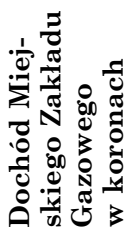 \\
\hline 1898 & 31 & 862 & 1008 & b.d. & 2186940 & b.d. & b.d. \\
\hline 1899 & 39,6 & 862 & b.d. & b.d. & 2457490 & b.d. & b.d. \\
\hline 1900 & 55,6 & 1464 & b.d. & 21031 & 2742680 & 809255 & 145934 \\
\hline 1901 & 68,1 & 1669 & 800 & b.d. & 3134550 & b.d. & b.d. \\
\hline 1902 & 73,7 & 1792 & b.d. & b.d. & 3227900 & 862216 & 87351 \\
\hline 1903 & 78,1 & 1872 & b.d. & 25101 & 3326040 & 888198 & 106233 \\
\hline 1904 & 80,2 & 1906 & b.d. & 27161 & 3587090 & 943092 & 140920 \\
\hline 1905 & 85,3 & 1964 & b.d. & 29156 & 3933000 & 1073123 & 200955 \\
\hline 1906 & 99,4 & 2266 & 712 & 31306 & 4385000 & 1142950 & 174012 \\
\hline 1907 & 123,6 & 2867 & 400 & 35215 & 4955830 & 1171550 & 149020 \\
\hline 1908 & 129,7 & 2991 & 348 & 40626 & 5383600 & 1372007 & 139189 \\
\hline 1909 & 142,2 & 3464 & 395 & 45042 & 5983060 & 1502522 & 141987 \\
\hline 1910 & 150,7 & 3541 & b.d. & 49748 & 6148860 & 1549746 & 382207 \\
\hline 1911 & b.d. & 3685 & b.d. & b.d. & 6608320 & 1664317 & b.d. \\
\hline 1912 & b.d. & 3736 & 304 & b.d. & 7129100 & b.d. & b.d. \\
\hline 1913 & b.d. & 3939 & 282 & b.d. & 7629740 & b.d. & b.d. \\
\hline
\end{tabular}

Legenda: * nie dotyczy instalacji gazowych ułożonych w nieruchomościach; b.d. - brak danych.

Źródło: Sprawozdanie prezydenta król. stot. miasta Lwowa [M. Michalskiego] z trzyletniej działalności reprezentacji miejskiej, magistratu i zaktadów miejskich w latach 1905, 1906 i 1907, Lwów 1908, s. 17; Sprawozdanie prezydenta król. stoł. miasta Lwowa [S. Ciuchcińskiego] z trzyletniej działalności reprezentacji miejskiej, magistratu i zakładów miejskich w latach 1908, 1909, 1910, Lwów 1911, s. 15-16; „Wiadomości statystyczne o mieście Lwowie” 12, 1910, s. 168-171; „Wiadomości statystyczne o mieście Lwowie” 13, 1911, s. 178-179; „Lwów w cyfrach. Miesięcznik statystyczny” 1-8, 1906-1913.

Mariackim i Halickim. Era elektryfikacji na dobre zaczęła się we Lwowie, kiedy w latach 1907-1910 rozbudowano linie tramwaju elektrycznego i wybudowano nowa, znacznie większą elektrownię miejską na Persenkówce ${ }^{85}$. Mogła ona wytwarzać energię elektryczna, której cena

${ }^{85}$ H. Feldstein, Sprawozdanie o budowie Miejskiego Zaktadu Elektrycznego $i$ rozszerzeniu kolei elektrycznej we Lwowie $w$ latach 1907, 1908 i 1909, Lwów 1911; W. Schivelbusch, dz. cyt., s. 20-25, 50-52; D. Schott, Empowering European Cities. Gas and Electricity in the Urban Environment, w: Urban Machinery Inside Modern European Cities, red. M. Hård, T. Misa, Cambridge (MA) 2008, s. 165-186. 
była osiagalna dla średniozamożnych mieszkańców miasta, gdyż po 1908 r. wielu właścicieli nowych kamienic zdecydowało się na zamontowanie sieci elektrycznej. Nie oznaczało to jednak eliminacji oświetlenia gazowego we Lwowie. Przeciwnie, gaz ciagle pozostawał tanim źródłem energii służącym do oświetlania ulic, a jego produkcja zwiększała się, przysparzając miastu największych dochodów spośród wszystkich miejskich przedsiębiorstw. Jako źródło energii gaz przegrywał jedynie na polu paliwa służącego do poruszania motorów, gdyż te elektryczne okazywały się bardziej wydajne. Z tego względu we Lwowie ostatecznie w $1911 \mathrm{r}$. zaprzestano użytkowania motorów gazowych, które zastapiły motory elektryczne ${ }^{86}$. Można zatem stwierdzić, że obydwie technologie oświetlania przed I wojną światową bardziej się uzupełniały, niż ze sobą konkurowały. Zwłaszcza, że gaz ciagle był znacząco tańszy od elektryczności ${ }^{87}$.

W historii przemysłu gazowniczego w stolicy Galicji możemy zauważyć wyraźnie różniące się od siebie okresy. W pierwszym powstawał zakład gazowy należący do prywatnej spółki. Z czasem okazało się, że spółka ta, próbując utrzymać monopol na rynku, przyczyniała się do stagnacji gazownictwa (mały wzrost produkcji, ograniczona dostępność produktu). Narastający kryzys przezwyciężyła komunalizacja zakładu gazowego w 1898 r. Rok ten stanowi wyraźną cezurę, gdyż w kolejnych latach możemy obserwować znaczący wzrost produkcji gazu przy jednoczesnym spadku jego ceny. Wówczas gaz stał się powszechnie dostępny dla lwowian. Miejski samorząd w ramach podjętych inwestycji zdecydował się na znacząca rozbudowę i modernizację gazowni w oparciu o aktualnie stosowane technologie produkcji gazu. Wykorzystywano przy tym nie tylko węgiel, ale także oleje naftowe, stanowiące produkty uboczne z procesu destylacji ropy naftowej. Warto zauważyć, że pierwszą w Galicji miejską gazownię olejowa, wytwarzająca gaz z olejów naftowych, wybudował w Stanisławowie inż. Julian Wang w 1874 r. Przy modernizacji gazowni we Lwowie korzystano z doświadczeń tego społecznie zaangażowanego technika ${ }^{88}$.

${ }^{86}$ W styczniu 1911 r. odnotowano ostatnie zużycie gazu dla motorów gazowych; zob. „Lwów w Cyfrach. Miesięcznik Statystyczny” 6, 1911, nr 1, s. 5; L. Czajkowski, Porównanie kosztów energii elektrycznej i gazu, „Czasopismo Techniczne” (Lwów) 30, 1912, nr 31-32, s. 404-405, 416-419.

${ }^{87} \mathrm{M}$. Altenberg, O postepie techniki lamp żarowych, „Czasopismo Techniczne” (Lwów) 23, 1905, nr 11, s. 194. Na temat porównania rentowności oświetlenia gazowego i elektrycznego zob. B. Szapiro, Oświetlenie elektryczne. Wykład popularny dla techników, Warszawa 1901, s. 109-117.

${ }^{88}$ Odnośnie do gazowni olejowej w Stanisławowie zob.: DALO, f. 599, op. 1, sp. 5, Sprawozdanie w sprawie powiększenia gazowni miejskiej, oprac. A. Teodorowicz, 
Powyższe spostrzeżenia sa symptomatyczne dla funkcjonowania przemysłu w wielkich miastach monarchii habsburskiej i Niemiec w latach 1860-1914. Pomimo wyraźnych regionalnych zróżnicowań, politykę samorządów miejskich coraz wyraźniej charakteryzowała tendencja do budowania struktury miasta „opiekuńczego”, którego wspólnota jest właścicielem infrastruktury i zakładów przemysłowych, będących dostawcami produktów i usług dla mieszkańców. Taka politykę zapoczątkowały największe miasta monarchii, jak Wiedeń, Praga i Budapeszt. Uważano, że bardziej korzystna - z punktu widzenia mieszkańców - będzie sytuacja, w której to municypia realizują inwestycje, następnie nimi zarządzają i czerpią z nich ograniczone dla dobra mieszkańców zyski ${ }^{89}$.

W końcu XIX w. władze Lwowa, wzorując się na powyższych tendencjach, wcieliły je w życie, przejmując rolę głównego inicjatora „rozwoju” i „modernizacji” gospodarki miejskiej. Odnośnie do interesującego nas wątku przemysłu gazowniczego wypada zauważyć, że w tym okresie władzom miejskim szczególnie musiała imponować wiodąca rola Pragi, jako miasta zarządzającego najbardziej zaawansowanymi technicznie zakładami gazowymi. Władze Pragi jako pierwsze w monarchii zdecydowały się zainwestować kapitał w budowę zakładu gazowego w $1867 \mathrm{r}$. Lecz dopiero podjęta w 1887 r. na wielką skalę rozbudowa kolejnej gazowni, w przyłączonej do miasta dzielnicy Holešovice (w miejscu już istniejącej od 1874 r. $)^{90}$, stała się pouczajacym przykładem dla Wiednia, a potem także dla innych miast i w końcu Lwowa. Warto zauważyć w tym kontekście, że elity polityczne zarówno Królestwa Czech, jak też Galicji i Lodomerii miały ambicje, aby uzyskać w Przedlitawii status polityczny porównywalny z tym, jakie uzyskało w 1867 r. Królestwo Węgier. W ramach tych dążeń koncentrowano się na rozwoju kultury, gospodarki i przemysłu, co łączyło się także z emancypacją narodową mieszkańców monarchii. W tym względzie przejęcie m.in. przemysłu gazowniczego przez miejskie samorządy uchodziło za oddanie

Lwów, 22 IV 1905 r., k. 5v-6v; O gazie olejnym, „Nafta. Organ Krajowego Towarzystwa Naftowego” 6, 1898, nr 9, s. 92; Ś.p. Juljan Wang, „Słowo Polskie” 4 V 1910, s. 6; K. Broński, Rozwój społeczno-gospodarczy Stanisławowa w latach 1867-1939, Kraków 1999, s. 115-116. O rozwoju technologii produkcji gazu por. D. Matthews, The Technical Transformation of the Late Nineteenth-Century Gas Industry, „The Journal of Economic History" 47, 1987, nr 4, s. 967-980.

${ }^{89}$ G. Melinz, S. Zimmermann, dz. cyt., s. 142-144.

90 R. Riedl, Historie plynárenství..., s. 71-73; J. Kohout, J. Vančura, Praha 19. a 20. století. Technícke proměny, Praha 1986, s. 83-84; G. Melinz, S. Zimmermann, dz, cyt., s. 150. 
znaczących sektorów gospodarki lokalnej w „czeskie ręce”91. Analogicznie politykę gospodarczą miasta interpretowano we Lwowie, stąd też władze miasta starały się, na ile to było możliwe, zlecać realizację rozbudowy gazowni polskim przedsiębiorcom i wykorzystywać w procesie produkcji gazu krajowe surowce energetyczne. Mam nadzieję, że powyższe rozważania przyczynią się do lepszego zrozumienia procesów modernizacyjnych, jakie w okresie autonomicznym zaszły na obszarze byłej Galicji.

\section{Bibliografia}

Brunckhorst H.-D., Kommunalisierung im 19. Jahrhundert dargestellt am Beispiel der Gaswirtschaft in Deutschland, München 1978.

Hoszowski S., Ekonomiczny rozwój Lwowa w latach 1772-1914, Lwów 1935.

Körting J., Geschichte der deutschen Gasindustrie mit Vorgeschichte und bestimmenden Einflüssen des Auslandes, Essen 1963.

Melinz G., Zimmermann S., Die aktive Stadt. Kommunale Politik zur Gestaltung städtischer Lebensbedingungen in Budapest, Prag und Wien (1867-1914), w: Wien - Budapest - Prag. Blütezeit der Habsburgermetropolen. Urbanisierung, Kommunalpolitik, gesellschaftliche Konflikte (1867-1918), red. G. Melinz, S. Zimmermann, Wien 1996, s. 140-176.

Miasto Lwów w okresie samorzadu 1871-1895, Lwów 1896.

Riedl R., Urzadzenia i ruch gazowni, tłum. L. Obidowicz, J. Czaplicka, Warszawa 1952.

Schivelbusch W., Disenchanted Night. The Industrialisation of Light in the Nineteenth Century, tłum. A. Davis, Berkeley-Los Angeles 1988.

Sroka Ł.T., Rada Miejska we Lwowie w okresie autonomii galicyjskiej 1870-1914. Studium o elicie wtadzy, Kraków 2012 (Uniwersytet Pedagogiczny im. Komisji Edukacji Narodowej w Krakowie. Prace Monograficzne, nr 621).

Teodorowicz A., O rozwoju gazowni we Lwowie, „Przegląd Gazowniczy. Organ Zrzeszenia Gazowników Polskich w Warszawie" 1, 1921, nr 1-2, s. 3-10, $26-30$.

Tomory L., Progressive Enlightenment. The Origins of the Gaslight Industry 1780-1820, Cambridge (MA)-London 2012 (Transformations: Studies in the History of Science and Technology).

Wessel H., Die Versorgung von Kommunen mit Wasser, Gas und elektrischer Energie von etwa 1850 bis 1914, w: Kommunalisierung im Spannungsfeld

91 J. Hájek, Proměny hospodářství: od tradiční výroby k industiální, w: České země v 19. století. Proměny společnosti v moderní dobé, t. 1, red. M. Hlavačka i in., Praha 2014, s. $364-374$. 
von Regulierung und Deregulierung im 19. und 20. Jahrhundert, red. J. Wysocki, Berlin 1995 (Schriften des Vereins für Socialpolitik. Gesellschaft für Wirtschafts- und Sozialwissenschaften. Neue Folge, 240), s. $49-90$.

Tomasz Dywan

Gas industry in Lviv in 1856-1914: a contribution to the history of the city's industrialisation

(Summary)

The article describes the circumstances of the construction of gasworks and gas pipeline network in the city of Lviv by the German Continental Gas Company of Dessau in 1858. The gas lighting was seen as a modernization of the capital city of the country which was regarded as the most backward in the Habsburgs' state. Under changing political conditions, after the reform of the political system of the 1860s, the local government of Lviv decided that the gasworks would be taken over by the city, which led to a conflict with the investor. This was also the reason for the stagnation of Lviv's gas supply system in the 1880s. After the gasworks was taken over by the city in 1898, its significant development and modernisation was initiated under the leadership of Adam Teodorowicz, but it was brought to an abrupt halt by the outbreak of the war. By this time, recent technologies of gas production were implemented and the process of production-support was partly mechanised. As regards technological solutions, the gasworks in Lviv was no worse than other gasworks in other European cities. At that time, gas, despite competition in the form of paraffin and electricity, was a cheap fuel used for lighting, but also for cooking and heating. The circumstances of the communalisation of the gasworks in Lviv indicate that, like in big cities of Germany and Austro-Hungary, the municipal government decided to take over strategic companies which provided mass transport services (trams), electricity, and gas. It was thought to be much better if such enterprises had been in the hands of municipal authorities.

Tomasz Dywan - adiunkt w Instytucie Historycznym Uniwersytetu Wrocławskiego. Doktor nauk historycznych, autor pracy Ksztattowanie kultury prowincjonalnej $w$ sanktuariach maryjnych na kresach potudniowo-wschodnich dawnej Rzeczypospolitej (2014). Swoje zainteresowania badawcze koncentruje na religijności i kulturze dawnej Rzeczypospolitej, a także historii nauki i techniki, ze szczególnym uwzględnieniem Europy Środkowej od XVI do początków XX w. 
Tomasz Dywan - PhD, assistant professor at the Institute of History of the University of Wrocław; the author of the book Ksztattowanie kultury prowincjonalnej $w$ sanktuariach maryjnych na kresach potudniowo-wschodnich dawnej Rzeczypospolitej (Shaping of the provincial culture in Catholic Marian shines in the former south-eastern borderlands of Polish-Lithuanian Commonwealth, 2014); his scholarly interest focus on the religiosity and culture of the old Commonwealth, but also on the history of science and technology with special emphasis on Central Europe from the $16^{\text {th }}$ to the early $20^{\text {th }}$ century.

E-mail: dywan.tomasz@uwr.edu.pl. 